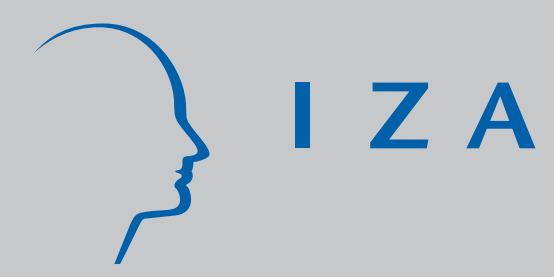

IZA DP No. 3968

India's Increasing Skill Premium:

Role of Demand and Supply

Mehtabul Azam

J anuary 2009 


\title{
India's Increasing Skill Premium: Role of Demand and Supply
}

\author{
Mehtabul Azam \\ Southern Methodist University \\ and IZA
}

Discussion Paper No. 3968

January 2009

\author{
IZA \\ P.O. Box 7240 \\ 53072 Bonn \\ Germany \\ Phone: +49-228-3894-0 \\ Fax: +49-228-3894-180 \\ E-mail: iza@iza.org
}

Any opinions expressed here are those of the author(s) and not those of IZA. Research published in this series may include views on policy, but the institute itself takes no institutional policy positions.

The Institute for the Study of Labor (IZA) in Bonn is a local and virtual international research center and a place of communication between science, politics and business. IZA is an independent nonprofit organization supported by Deutsche Post Foundation. The center is associated with the University of Bonn and offers a stimulating research environment through its international network, workshops and conferences, data service, project support, research visits and doctoral program. IZA engages in (i) original and internationally competitive research in all fields of labor economics, (ii) development of policy concepts, and (iii) dissemination of research results and concepts to the interested public.

IZA Discussion Papers often represent preliminary work and are circulated to encourage discussion. Citation of such a paper should account for its provisional character. A revised version may be available directly from the author. 


\section{ABSTRACT}

\section{India's Increasing Skill Premium: Role of Demand and Supply*}

The tertiary-secondary (college-high school) wage premium has been increasing in India over the past decade, but the increase differs across age groups. The increase in wage premium has been driven mostly by younger age groups, while older age groups have not experienced any significant increase. This paper uses the demand and supply model with imperfect substitution across age groups developed in Card and Lemieux (2001) to explain the uneven increase in the wage premium across age groups in India. The findings of this paper are that the increase in the wage premium has come mostly from demand shifts in favor of workers with a tertiary education. More importantly, the demand shifts occurred in both the 1980s and 1990s. Relative supply has played an important role not only determining the extent of increase in wage premium, but also its timing. The increase in relative supply of tertiary workers during 1983-1993 offset the demand shift, limiting the wage premium increase. But during 1993-1999, the growth rate of the relative supply of tertiary workers decelerated, while relative supply was virtually stagnant during 1999-2004. Both of these periods saw an increase in the wage premium as the countervailing supply shift was weak.

JEL Classification: J20, J23, J31

Keywords: India, wage premium, tertiary (college), secondary (high school)

Corresponding author:

Mehtabul Azam

Department of Economics

Southern Methodist University

Dallas, TX 75275-0496

USA

E-mail:mazam@smu.edu

\footnotetext{
*I am grateful to Daniel Millimet, Andreas Blom for comments and advice. Any error remains mine.
} 


\section{Introduction}

India's inability to reduce poverty in spite of a sustained period of high GDP growth during the last decade has drawn a great amount of interest. ${ }^{1}$ While the poverty ratio declined from 36 percent in 1993-94 to 27.5 percent in 2004-05, the number of poor remains at 302 million. ${ }^{2}$ Recently, there is a growing focus on wage inequality in post-1991 reform era. The interest in wage inequality is due to two reasons. First, after four decades of importsubstitution industrialization strategy, India initiated a drastic liberalization of its external sector and industrial policy in 1991. Second, there is a growing recognition that greater income inequality tends to slow poverty reduction (Ravallion and Chen, 1997). The effects of trade liberalization on wage inequality in developing countries have been quite varied. The East Asian newly-industrialized economies experienced a reduction in wage inequality after opening with a strong export-orientation in the 1960s and 1970s. However, for a number developing countries that opened up to trade more recently, liberalization did not lead to reduction in wage inequality; on the contrary, some have seen an increase in the skilled wage premium (Arbache et al., 2004). ${ }^{3}$

India also experienced both liberalization of trade and rising wage inequality. Dutta (2005) finds that the wage inequality increased in India over 1983-1999. Chamarbagwala (2006) divides the total labor force into 100 labor groups (two sex groups, five education groups and ten experience groups) following Katz and Murphy (1992) and finds that changes in relative wages during 1983-1999 is driven mostly by increase in demand. Kijima (2006) explores the wage inequality in urban India during 1983-1999 using the Juhn et al. (1993) methodology and finds that wage inequality in India started increasing before 1991 and the increase is attributable to an increase in the returns to tertiary education.

While most of the literature on wages in India concentrate on explaining wage inequality, the wage premium itself has not been studied in detail. The rising wage premium for skilled workers since 1980s in many OECD countries is well-documented. In the United States, for example, Katz and Autor (1999) estimate that the real wages of high school drop-outs, the least skilled workers, fell over the 1963-1995 period (by about -4.5 percent), while the

\footnotetext{
${ }^{1}$ See 'The Great Indian Poverty Debate' (Deaton and Kozel, 2005) for a collection of articles exploring various issues on poverty in India.

${ }^{2}$ These estimates are based on Uniform Recall Period. On Mixed Recall Period the poverty rate declined from 26.1 percent in 1999-00 to 21.8 percent in 2004-05. The change in Recall Period by National Sample Survey in 1999-00 consumer survey has given rise to a considerable amount of controversy in Poverty Estimates (Deaton, 2003; Himansu and Sen, 2004).

${ }^{3}$ Arbache et al. (2004) survey increase in wage premium following liberalization in Brazil (Green et al., 2001), Mexico (Hanson and Harrison, 1999; Robertson, 2000), Chile (Beyer, Rojas, and Vergara, 1999), Morocco (Currie and Harrison, 1997), Costa Rica (Robbins and Gindling, 1999) and Columbia (Robbins, 1996a).
} 
real wages of college graduates rose sharply (by about 22.4 percent). But, a considerable amount of controversy exists about the extent to which the increase in the wages of skilled workers can be explained by shifts in labor demand favoring high-skilled labor at the expense of low-skilled labor (Juhn et al., 1993; Bound and Johnson, 1992; Autor et al., 1998) or a deceleration in the relative supply of high-skilled labor compared to low skilled-labor (Katz and Murphy, 1992; Card and Lemieux, 2001).

The Indian labor force can be broadly classified into five different skill categories depending on education level: tertiary, secondary, middle, primary and below primary (which includes the illiterate). ${ }^{4}$ Tertiary is the highest skill group, while below primary is the lowest skill group. Figure 1 plots the wage gaps for different skill groups over the past two decades in urban India. The wage gap is calculated using individual-level data; details are given in the data section and data appendix. The wage gap between adjacent skill groups at the lower end shows very little change over the last two decades, while the wage gap between workers with secondary and middle schooling shows a modest increase of 8 percent during the same period. But, the major beneficiaries are tertiary graduate (college degree) workers whose gap with the adjacent lower education group, i.e., secondary graduate (high school) workers, has shown a considerable increase in the 1990s for regular employed workers. ${ }^{5}$ The wage gap between tertiary and secondary graduate workers increased in last two decades from 34 percent to 50 percent. ${ }^{6}$ As secondary graduate workers themselves experienced a modest increase in wages relative to lower skill groups, this implies the wage gap of tertiary graduate workers experienced a major increase compared to all other education groups.

Interestingly, most of the increase in the wage gap is concentrated after 1991, coinciding with liberalization and high GDP growth rate. Also, this rise in wage premium for tertiary graduate workers compared to secondary graduate workers differs across age groups. The wage gap rose from 27 percent to 55 percent for the younger group (age 23-32); while it decreased from 42 percent to 41 percent for the older group (48-57) (Figure 2). ${ }^{7}$ Similar trends have also been observed in the US, UK and Canada (Card and Lemieux, 2001).

The trends observed in the tertiary-secondary wage premium in India raise two questions. First, is imperfect substitutability across age groups the reason why different age groups experienced different changes in the wage premium over time? Second, what led to the sudden increase in the tertiary-secondary wage premium in 1990s?

\footnotetext{
${ }^{4}$ The pattern of Indian education system is given in the appendix Table A1.

${ }^{5}$ Regular employed workers are defined as individuals who worked in others' farm or non-farm enterprises and, in return received salary or wages on a regular basis (i.e., not on the basis of daily or periodic renewal of work contract).

${ }^{6}$ In rural India, tertiary-secondary wage gap rose from 25 percent to 41 percent over the last two decades.

${ }^{7}$ Similar but less accentuated trends are observed in rural India also.
} 
In a seminal paper, Katz and Murphy (1992) demonstrate how the relative supply of college graduates to high school graduates combined with a linearly increasing trend in labor demand for college graduates drives the relative wages of college graduates in the US. Card and Lemieux (2001) refine this finding for the US, UK and Canada by allowing for imperfect substitutability across age groups. This paper follows the approach of Card and Lemieux (2001) to assess whether the age group specific relative supply combined with steadily increasing demand for skilled labor, provides an explanation for the observed changes in the wage premium between tertiary and secondary graduate workers. ${ }^{8}$

The paper contributes to the existing literature in three ways. First, we assess the role played by changes in relative demand and relative supply of tertiary graduate workers in shaping relative wages of the tertiary graduate workers. Our supply measure incorporates the imperfect substitutability across age groups. Second, we obtain estimates of the elasticity of substitution between tertiary and secondary graduate workers and the elasticity of substitution across age groups, which would be a first for India, to our best knowledge. Third, we extend the period of study through 2004 by incorporating new data. In extending the analysis to the more recent period, we are able to shed light on some important trends in relative supply which differs from the earlier period.

The findings of the paper are as follows. First, the relative supply of tertiary graduate workers, after increasing in the 1980s and early 1990s, stopped growing between 1999 and 2004. Second, the demand shifts in favor of tertiary graduate workers occurred both in the 1980s as well as in the 1990s. The changes in aggregate relative supply explain why wage premium was stable in the 1980s and increased in the late 1990s. An increase in the aggregate relative supply of tertiary graduate workers kept a check on the tertiary-secondary wage premium in the 1980s. However, between 1993 and 1999, the increase in relative supply of tertiary graduate workers decelerated and, combined with increasing demand, led to an increase in the wage premium. Between 1999 and 2004, the relative supply of tertiary graduate workers changed little and the shift in demand led to a further increase in the wage premium. Third, there exists imperfect substitutability across age groups. Our main conclusions regarding demand and supply are quite robust to alternative specifications and samples used.

The remainder of the paper is organized as follows. Section 2 details the empirical strategy. Section 3 describes the data and data trends. Section 4 discusses the results and alternative specifications. Section 5 concludes.

\footnotetext{
${ }^{8}$ The focus on the tertiary-secondary wage gap is motivated by the fact that this gap has increased sharply during the last decade. Also, prior studies pointing out that the return to tertiary education is the main contributor to wage inequality warrants this focus on tertiary graduate workers.
} 


\section{Empirical Strategy}

\subsection{Theoretical Framework}

Following Card and Lemieux (2001), assume that aggregate output at time $t$ depends on two CES sub-aggregates of secondary $(S)$ and tertiary $(T)$ graduate labor:

$$
\begin{aligned}
& S_{t}=\left[\sum_{j}\left(\alpha_{j} S_{j t}^{\eta}\right)\right]^{\frac{1}{\eta}} \\
& T_{t}=\left[\sum_{j}\left(\beta_{j} T_{j t}^{\eta}\right)\right]^{\frac{1}{\eta}}
\end{aligned}
$$

where $-\infty<\eta \leq 1$ is a function of the partial elasticity of substitution $\left(\sigma_{A}\right)$ between different age groups $(j)$ with the same level of education $\left(\eta=1-1 / \sigma_{A}\right) ; \alpha_{j}$ and $\beta_{j}$ are relative efficiency parameters of secondary and tertiary graduate workers (assumed to be fixed over time). In principle, $\eta$ could be different for different educational groups, but for simplicity assume $\eta$ to be identical across education groups.

Aggregate output in period $t, Y_{t}$, is a function of secondary graduate labor, tertiary graduate labor and technology efficiency parameters, $\theta_{S t}$ and $\theta_{T t}$ :

$$
Y_{t}=f\left(S_{t}, T_{t} ; \theta_{S t}, \theta_{T t}\right)
$$

Assume that aggregate production function is CES:

$$
Y_{t}=\left(\theta_{S t} S_{t}^{\rho}+\theta_{T t} T_{t}^{\rho}\right)^{\frac{1}{\rho}}
$$

where $-\infty<\rho \leq 1$ is a function of elasticity of substitution $\left(\sigma_{E}\right)$ between the two education groups $\left(\rho=1-1 / \sigma_{E}\right)$. In this setting, the marginal product of labor for a given ageeducation group depends on both the group's own supply of labor and the aggregate supply of labor in its education category. In particular, the marginal product of secondary graduate workers in age group $j$ is:

$$
\begin{aligned}
\frac{\partial Y_{t}}{\partial S_{j t}} & =\frac{\partial Y_{t}}{\partial S_{t}} \times \frac{\partial S_{t}}{\partial S_{j t}} \\
& =\theta_{S t} S_{t}^{\rho-\eta} \Psi_{t} \times \alpha_{j} S_{j t}^{\eta-1}
\end{aligned}
$$

where $\Psi_{t}=\left(\theta_{S t} S_{t}^{\rho}+\theta_{T t} T_{t}^{\rho}\right)^{\frac{1}{\rho}-1}$. 
Similarly, the marginal product of tertiary graduate workers in age group $j$ is:

$$
\begin{aligned}
\frac{\partial Y_{t}}{\partial T_{j t}} & =\frac{\partial Y_{t}}{\partial T_{t}} \times \frac{\partial T_{t}}{\partial T_{j t}} \\
& =\theta_{T t} T_{t}^{\rho-\eta} \Psi_{t} \times \beta_{j} T_{j t}^{\eta-1} .
\end{aligned}
$$

Efficient utilization of different skill groups requires that relative wages are equated to relative marginal products. Under this assumption, the ratio of the wage rate of tertiary graduate workers in age group $j\left(w_{j t}^{T}\right)$ to the wage of secondary graduate workers in the same age group $j\left(w_{j t}^{S}\right)$ satisfies the following equation:

$$
\log \left(\frac{w_{j t}^{T}}{w_{j t}^{S}}\right)=\log \left(\frac{\theta_{T t}}{\theta_{S t}}\right)+(\rho-\eta) \log \left(\frac{T_{t}}{S_{t}}\right)+\log \left(\frac{\beta_{j}}{\alpha_{j}}\right)+(\eta-1) \log \left(\frac{T_{j t}}{S_{j t}}\right)
$$

If the relative employment ratios are taken as exogenous, equation (7) leads to a simple model for the observed tertiary-secondary wage gap for workers in age group $j$ and year $t$. Substituting for $\rho$ and $\eta$ yields:

$$
r_{j t}=\log \left(\frac{w_{j t}^{T}}{w_{j t}^{S}}\right)=\log \left(\frac{\theta_{T t}}{\theta_{S t}}\right)+\log \left(\frac{\beta_{j}}{\alpha_{j}}\right)+\left[\frac{1}{\sigma_{A}}-\frac{1}{\sigma_{E}}\right] \log \left(\frac{T_{t}}{S_{t}}\right)-\frac{1}{\sigma_{A}} \log \left(\frac{T_{j t}}{S_{j t}}\right)+e_{j t}
$$

where $e_{j t}$ reflects sampling variation in measured wage premium or any other source of variation in age group-specific wage premiums. Equation (8) can be rearranged as:

$$
r_{j t}=\log \left(\frac{\theta_{T t}}{\theta_{S t}}\right)+\log \left(\frac{\beta_{j}}{\alpha_{j}}\right)-\frac{1}{\sigma_{E}} \log \left(\frac{T_{t}}{S_{t}}\right)-\frac{1}{\sigma_{A}}\left[\log \left(\frac{T_{j t}}{S_{j t}}\right)-\log \left(\frac{T_{t}}{S_{t}}\right)\right]+e_{j t} .
$$

According to (9), the tertiary-secondary wage gap for a given age group depends on both the aggregate relative supply of tertiary graduate labor $\left(T_{t} / S_{t}\right)$ in period $t$, and on the age group specific relative supply of tertiary graduate labor $\left(T_{j t} / S_{j t}\right)$. Any change in age group specific relative supplies would be expected to shift the age profile of the tertiary-secondary wage gap, with an effect that depends on the size of $1 / \sigma_{A}$.

\subsection{Implementation}

Direct estimation of (9) is not feasible since $T_{t}$ and $S_{t}$ are not observable. As shown in (1) and (2), $T_{t}$ and $S_{t}$ are dependent on $\alpha_{j}$ 's, $\beta_{j}$ 's and $\sigma_{A}$. Thus, following Card and Lemieux (2001), a two-step estimation procedure is utilized. In the first step, estimates of the $\alpha_{j}$ 's, $\beta_{j}$ 's and $\sigma_{A}$ are obtained. In the second step, the resulting estimates of $T_{t}$ and $S_{t}$ are used 
to estimate (9).

\section{Step I}

In the first step, $\sigma_{A}$ is estimated from a regression of age-group specific tertiary-secondary wage gaps on age group specific relative supplies of tertiary graduate labor, age effects (which absorb the relative productivity effect $\log \left(\beta_{j} / \alpha_{j}\right.$ ), and time effects (which absorb the combined relative technology shock and any effect of aggregate relative supply):

$$
r_{j t}=b_{j}+d_{t}-\left(1 / \sigma_{A}\right) \log \frac{T_{j t}}{S_{j t}}+e_{j t}
$$

where $b_{j}$ and $d_{t}$ are the age and year effects, respectively. Given the estimate of $1 / \sigma_{A}$, the

relative efficiency parameters, $\alpha_{j}$ 's and $\beta_{j}$ 's, can be computed by equating marginal products to wages. Taking logs yields:

$$
\begin{aligned}
& \log \left(w_{j t}^{S}\right)+\left(1 / \sigma_{A}\right) \log S_{j t}=\log \left(\theta_{S t} S_{t}^{\rho-\eta} \Psi_{t}\right)+\log \alpha_{j} \\
& \log \left(w_{j t}^{T}\right)+\left(1 / \sigma_{A}\right) \log T_{j t}=\log \left(\theta_{T t} T_{t}^{\rho-\eta} \Psi_{t}\right)+\log \beta_{j} .
\end{aligned}
$$

The left-hand side of these equations can be estimated using the first-step estimate of $1 / \sigma_{A}$, while the leading term on the right-hand side of (11) and (12) can be replaced with a set of year dummies. Thus, the age group specific productivity factors, $\log \alpha_{j}$ and $\log \beta_{j}$, can be estimated by the age effects in a pair of regression models based on (11) and (12) that also include unrestricted year dummies.

\section{Step II}

Given the estimates of $\alpha_{j}$ 's, $\beta_{j}$ 's and $\eta$, the aggregate supplies of tertiary and secondary graduate labor can be constructed. With these estimates in hand, and some assumption concerning the time path of relative productivity term $\left(\theta_{T t} / \theta_{S t}\right)$, equation (9) can be estimated directly. Following the existing literature, assume that $\log \left(\theta_{T t} / \theta_{S t}\right)$ can be captured by a linear time trend and changes in labor supply are exogenous.

\section{Data}

\subsection{Description}

The analysis is based on individual-level household survey data from the Employment and Unemployment Schedule administered by the National Sample Survey Organization (NSSO), Government of India. Data from five rounds - conducted in 1983 (38th Round), 1987-88 (43rd Round), 1993-94 (50th Round), 1999-00 (55th Round) and 2004-05 (61st Round) - 
are used (referred as 1983, 1987, 1993, 1999 and 2004 in this paper). ${ }^{9}$ The data constitute a repeated cross section and contain information on household size and composition, social group, religion, monthly consumption, landholdings, demographic variables (age, gender, marital status), educational participation and attainment, and a detailed employment section on principal and subsidiary activities (industry, occupation, type and amount of wages earned, and intensity of each activity). Each survey covers about 120,000 households and over half a million individuals. Approximately 35 percent of the sample comes from urban areas; the remainder from rural areas. The sample of households is drawn based on a stratified random sampling procedure and all the analysis is done using survey weights.

In the data, workers are classified as self-employed, regular wage/salaried and casual labor. Wages are reported at current prices for regular wage/salaried and casual labor. State-specific rural-urban official poverty lines are used to deflate all wages to 1983 prices. Educational attainment is reported by levels of education achieved. ${ }^{10}$ The data classify 15 years or more of education as tertiary; 10-12 years of education is coded as secondary.

The analysis is restricted to urban regular wage/salaried workers, as more than nearly 65 percent of regular jobs with tertiary and secondary graduate workers are concentrated in urban areas. ${ }^{11}$ The estimated wage premiums are based on regular wage/salaried workers between the ages of 23 and 57, while relative education group supplies are constructed using all type of workers between 23 and $57 .{ }^{12,13}$ A detailed description of construction of the wage sample and estimation of the wage premium is given in the data appendix. Changes in employment shares of different skill groups in regular jobs over time are presented in Table 1. The employment share of tertiary graduates in regular jobs has gone up from 19 percent to 30 percent over the last two decades; an overall increase of 11 percent. The employment share of secondary graduates also saw a modest increase of 4 percent during the same period, and the lower skill groups have seen their shares decline.

\footnotetext{
${ }^{9} \mathrm{NSSO}$ conducts thick round surveys at five-year intervals (called 'Quinquennial Rounds'). The data before 1983 is not available.

${ }^{10}$ It is not possible to identify dropouts as they are grouped with the lower education level completed.

${ }^{11}$ The 1987 rural sample suffers from lots of missing data on wages. The sample size in higher age groups for the 1983 and 1993 rural samples becomes too restrictive to implement the empirical strategy for rural area separately. The attention to urban area only is consistent with some other studies (e.g. Kijima (2006), Kumar and Mishra (2005), Bhaumik and Chakravaty (2007)).

${ }^{12}$ It takes a minimum of 21 years of age to complete tertiary education. Choice of the lower age cut-off of 23 is to allow tertiary graduates to get into labor force. The upper cut-off of age is motivated by the fact that the retirement age is 58 - 62 depending on the state and nature of employer.

${ }^{13}$ Katz and Murphy (1992) pool together men and women in their analysis of the effect of aggregate relative supply on the college high school wage gap. Card and Lemieux (2001) also pool together both sexes in one of the specification. The percentage of female in wage premium sample is 14, 16.5, 17.8, 18 and 19, respectively in the five study years. We find similar results when we restrict our attention to male sample only (Table 5 ).
} 


\subsection{The Evolution of the Tertiary-Secondary Wage Premium}

The estimates of the wage premiums are reported in Table 2. They are based on the difference in mean log average weekly wages between regular workers with a tertiary degree and those with a secondary degree. ${ }^{14}$ Comparisons within a column of the table show the changing tertiary-secondary wage premium for a specific age group. For the age group 23-27, the wage premium increased between 1983 and 1987, remained approximately constant for next decade and then increased sharply between 1999 and 2004. The wage premium for the age group 28-32 also shows a steady upward trend. The wage premium rose for the age group 23-42 between 1999 and 2004, but for the older age groups 48-51 and 52-57, the wage premium did decrease during the same period. The overall increase in wage premium of tertiary graduate workers is mostly driven by younger age groups.

Comparisons within the rows of the table reveal the age profile of the tertiary-secondary wage gap at a point of time. Figure 3 plots these age profiles of the wage premium for different years. In 1987 and 1993 the entire age profile shifted down except for the two youngest age groups compared to 1983 age profile of wage premium. Incidentally, the late 1980s and early 1990s are associated with fiscal and balance of payments crises followed by structural adjustment in India. In 1999, the entire wage premium age profile shifts upwards compared to 1993 age profile, while in 2004, the upward shift compared to 1999 age profile is experienced only by the younger age groups (23-42 years old); the older age groups (43-57 years old) experienced downward shift compared to 1999. Overall, for the period 1983-2004, the tertiary-secondary wage premium is an increasing and slightly concave function of age.

The shifting age profiles suggest two separate forces underlie the evolution of the tertiarysecondary wage premium over time. The overall set of wage premia can rise or fall over time (as they appear to have done). On the other hand, the relative wage premia for specific age groups can rise or fall independently of the wage premiums for the other groups. The length of the sample period does not allow estimation of a complete age profile of wage premium for any single cohort, but the incomplete age profiles of different cohorts are plotted in Figure 4. The figure indicates upward shifts in the age profile of the wage premium for cohorts separated in birth by ten years.

\footnotetext{
${ }^{14}$ Katz and Murphy (2002) use similar measure for college graduates (16 years and more of education). An alternative used in the literature is exactly a college degree (i.e., 16 years of education). Card and Lemieux (2001) use both measures. We cannot distinguish graduates and post graduates as data do not distinguish them.
} 


\subsection{The Evolution of the Relative Supply}

Estimates of relative supplies of tertiary and secondary graduates are based on a broad sample of workers. All types of workers (regular, casual and self-employed) between the ages of 23 and 57 are included. Three different types of supply measures are used as a robustness check. The first supply measure is the number of hours supplied by each education group, which takes account of any difference in number of hours supplied by different education groups. The second is a simple count of number of the workers assuming each can potentially supply one unit of labor. The third is a simple count of the labor force, defined as workers plus those who are available or seeking work. The third measure takes into account the unemployed. Tertiary graduates are treated as pure tertiary equivalents, secondary graduates as pure secondary equivalents. Middle school graduates, those who have completed at least 8 but less than 10 years of education, are allocated to secondary school graduates weighted by their wage relative to secondary school graduates.

Figure 5 shows the evolution of the log of the relative fraction of tertiary versus secondary workers for two age groups: 23-27 year olds and 53-57 year olds. The figure is based on the hours supply measure; the other two supply measures show similar trends. The older group 53-57 experienced an upward trend throughout the study period, but the younger group has an almost stationary relative supply.

Educational attainment of a cohort is assumed to be approximately constant over time unless there is a very high percentage of late completion in a cohort. To check this hypothesis and further investigate the trends in relative supplies, the age and cohort effects are fitted to the relative fraction of tertiary graduate workers. Formally, suppose that the log supply ratio of workers in age group $j$ and year $t$ consists of a cohort effect for the group, $\lambda_{t-j}$ (dated by their year of birth), and an age effect $\phi_{j}$ :

$$
\log \left(\frac{T_{j t}}{S_{j t}}\right)=\lambda_{t-j}+\phi_{j}+e_{j t}
$$

$\lambda_{t-j}$ is assumed to be constant for a cohort as cohorts do not add much additional education after labor market entry, while $\phi_{j}$ is the age profile of relative labor supply assumed to be constant across cohorts. $\phi_{j}$ allows labor supply by education groups to differ over the life cycle. The model fits very well for all three supply measures, with $R^{2}$ exceeding 99 percent in each case. ${ }^{15}$ All age and cohort dummies in the model are statistically significant. The estimated cohort effects are plotted in Figure 6. There is a positive inter-cohort trend before the early 1960s, but the trend almost stagnated in the 1960s and early 1970s. There

\footnotetext{
${ }^{15}$ The results are given in appendix Table A2.
} 
is slight positive trend again in the late 1970s cohort.

\section{Results}

\subsection{Results}

In the first stage of the two-step estimation process, age group specific wage premium for different age groups in various years are regressed on the respective age group specific relative supply, year and age effects (equation 10). Since the wage premium across age groups in different years are estimated from different sample sizes and hence vary in precision, all the regressions are weighted by the inverse of the sampling variances of the estimated wage premia. The first-stage results for three different supply measures are presented in Table 3. Columns (1), (3) and (5) report results from the models including unrestricted year affects. The estimated effects of (log) age group specific relative supply on (log) age specific relative wage premium are statistically significant. Hence, age group specific supplies are important in determining age group specific wage premium.

Although the estimated effects of age group specific relative supply are dependent on the choice of supply measure used, the estimates are fairly close. The coefficient on the (log) age group specific relative labor supply lies between -0.168 using workers as the supply measure and -0.20 using labor force as the supply measure. As a result, the estimated elasticity of substitution across age groups lies between $5(=1 / 0.20)$ and $5.95(=1 / 0.168)$. These estimates are comparable in magnitude to those found by Card and Lemieux (2001) for the US, UK and Canada.

The estimated year effects which absorb the technology shock and the effect of changing aggregate relative supply do not show a statistically significant change during 1983-1993, but show a steep rise in 1999 and 2004. Since technology shocks and aggregate relative supply have opposite effects on the wage premium, much cannot be read into year effects until one knows the behavior of aggregate relative supply.

Column (2), (4) and (6) of Table 3, report the results of the same models except the year effects have been replaced with a linear time trend. Replacing the unrestricted year effects with a trend does not change the critical coefficients drastically, but the fit of the model deteriorates.

In the second stage, age group specific wage premia by year are regressed on both age group specific relative supplies and aggregate relative supplies of tertiary graduate workers (equation 9). Aggregate supplies are calculated using the estimates of elasticity across age groups estimated in first stage and the tertiary, secondary efficiency parameters which are 
estimated by fitting equations (11) and (12). ${ }^{16}$ The relative technology shock variable is assumed to follow a linear time trend. ${ }^{17}$ The results are presented in columns (1), (2) and (3) of Table 4.

Aggregate relative supply has a statistically significant effect on the wage premium. The estimated coefficient on aggregate relative labor supply lies between - 0.464 using labor force as the supply measure and -0.491 using hours as the supply measure. As a result, the elasticity of substitution between tertiary and secondary equivalent workers lies between $2.04(=1 / 0.491)$ and $2.16(=1 / 0.464)$. Evidence from other countries suggests an elasticity of substitution between tertiary and secondary graduates between 1.1 and $2.5 .{ }^{18}$ Thus, the estimated elasticity between 2 to 2.2 is consistent with other countries' experiences, especially from developing counties like Brazil and Columbia. Also, similar estimates are obtained for $\left(1 / \sigma_{A}\right)$ in both stages as predicted by the theoretical model.

The time trend variable is statistically significant and the coefficient implies an almost $7 \%$ increase in demand in each five-year period. Columns (4), (5) and (6) of Table 4 present the results of the same models except a post-1991 dummy is included to capture any significant change in demand in the post-1991 reform era. The belief that most of the increase in demand occurred in the 1990s is rejected as the post-1991 dummy is statistically insignificant.

The aggregate relative supply index that is used in the second-stage is plotted in Figure 7. The relative supply index shows that the relative supply of tertiary workers increased in the 1980s, while the rate of growth decreased between 1993 and 1999. However, the relative supply was virtually unchanged between 1999 and 2004. Given the trends in supply, an increase in the wage premium for tertiary workers could not have come without a shift in demand throughout the study period. The wage premium did not change during 1983-1987; it increased by 3 percent during 1987-1993. In both these periods, the aggregate supply of tertiary workers was increasing. The observed changes in wage premium between 19831993 is possible only if a positive demand shift negated or outweighed the positive supply shift. Similarly, during 1993-1999 and 1999-2004, there was a deceleration and stagnation, respectively, in relative supply. Considering that these two periods saw major increases in the wage premium, demand-side changes must have played a key role. Thus, a continual shift in demand combined with a stagnant relative supply is one potential explanation for the increase in the wage premium experienced in late 1990s (Figure 1).

\footnotetext{
${ }^{16}$ The estimated efficiency parameters for age groups are reported in the appendix Table A3.

${ }^{17}$ Adding higher order terms in time (i.e., time square and time cubic) does not improve the fit of the model. Moreover, with higher order terms in the model, both the trend and higher order terms become insignificant and the sign of the coefficient on the relative supply index also changes to positive, which is counter-intuitive. This suggests steady demand hypothesis holds, i.e., technological change happens at constant rate, which is captured by a linear time trend.

${ }^{18}$ Appendix Table A4 presents elasticity estimates from some other countries.
} 


\subsection{Alternative specifications}

Some alternative specifications are considered to check further the robustness of the estimates with respect to supply measures and samples used.

First, since this paper's aim is to explain the wage premium between completed tertiary and secondary education, the supply measure is restricted to pure tertiary and pure secondary (i.e., middle school is excluded from the secondary supply measure). The age group specific relative supply is statistically significant at the $10 \%$ significance level using each of the three supply measures. ${ }^{19}$ The estimated elasticity of substitution between different age groups lies between $5.2(=1 / 0.190)$ and $6.25(=1 / 0.160)$. The estimated elasticity is very similar to the one estimated earlier using secondary equivalents as the supply measure. The results of the second-stage estimation are presented in Table 5. The estimated elasticity of substitution between tertiary and pure secondary workers lie between $1.96(=1 / 0.504)$ and $2.15(=1 / 0.465)$, which is very close to the estimates obtained when secondary equivalents are used as the supply measure. Importantly, the time trend is statistically significant and implies an almost $6.5 \%$ increase in demand in favor of tertiary graduate workers in each five-year period.

Second, workers with education level below secondary (i.e., middle, primary, below primary and illiterate) are allocated to secondary, weighted by their wages relative to secondary graduate workers. So our relative supply of tertiary workers reflects tertiary vs. non-tertiary. The age group specific relative supply is statistically significant in first stage. ${ }^{20}$ The estimated elasticity of substitution between different age groups lie between $5.61(=1 / 0.178)$ and $6.25(=1 / 0.160)$. The second stage results are presented in Table 6 . The estimated elasticity of substitution between tertiary and non-tertiary workers lie between $3.04(=1 / 0.328)$ and $3.25(=1 / 0.308)$. The elasticity between two education groups' workers is higher in this case. A higher elasticity implies a less affect on relative wages if relative supply changes. Importantly, the time trend is statistically significant and implies 7-8\% increase in demand in favor of tertiary graduate workers in each five-year period.

Third, both urban and rural areas and both sexes are pooled together to present an overall picture of India. The age group specific relative supply is statistically significant in first stage. ${ }^{21}$ The estimated elasticity of substitution between different age groups lie between $4.9(=1 / 0.205)$ and $6.33(=1 / 0.158)$. The results of second-stage estimation are presented in Table 7 . The estimated elasticity of substitution between the two education groups lie between $2.07(=1 / 0.481)$ and $2.61(=1 / 0.383)$. The estimates are higher than the estimates

\footnotetext{
${ }^{19}$ The first-stage results are presented in the appendix Table A5.

${ }^{20}$ The first stage results are presented in appendix Table A6.

${ }^{21}$ The first-stage results are presented in the appendix Table A7.
} 
obtained using urban areas only. This implies that the elasticity of substitution between the two education groups in rural areas is higher than in urban areas. Also, the time trend is statistically significant and indicates 5.3-6.5\% demand growth in favor of tertiary graduate workers in each five-year period. The growth rate of demand in favor of the tertiary graduate workers is less in the pooled sample than the urban only sample, which indicates a lower growth rate of demand for skilled workers in rural areas compared to urban areas.

Fourth, the sample is restricted to urban men only for the estimation of the wage premium and supply measures. ${ }^{22}$ The wage premia for different age groups for males in different years are presented in Table 8 and shows trends similar to trends observed in sample with both sexes. The estimated elasticity of substitution between different age groups lie between 5.8 $(=1 / 0.172)$ and $7(=1 / 0.143) .{ }^{23}$ The estimated elasticity between different age groups in the male sample is higher than that found in the sample using both sexes. The second-stage estimation results are presented in Table 9. The estimated elasticity of substitution between the two education groups lie between $1.75(=1 / 0.572)$ and $1.85(=1 / 0.540)$. These estimates are a little lower than the baseline results obtained using both sexes. Importantly, the time trend variable is statistically significant and indicates an $8 \%$ demand growth in favor of tertiary graduate workers in each five-year period.

Figure 8 plots the aggregate relative supply of tertiary workers used in the second stage regressions for all the four alternative specifications discussed above. ${ }^{24}$ The aggregate supply measure for all the four specifications shows trends similar to what obtained in main results. Also, in all the specifications discussed above, the trend variable is statistically significant and implies a demand growth of $5-8 \%$ in favor of tertiary graduates in each five-year period.

\subsection{Discussion}

Our most important finding is the slowdown in the relative supply of tertiary workers in late 1990s. While the tertiary-secondary wage premium is driven mostly by demand shifts in favor of tertiary graduate workers that occurred both in the 1980s as well as in the 1990s, the increase in relative supply of tertiary graduate workers in the 1980s kept a check on the tertiary-secondary wage premium. But the countervailing shift in the relative supply becomes weak in late 1990s causing an increase in the wage premium. We also find that

\footnotetext{
${ }^{22}$ We also performed specification checks on urban male sample using pure tertiary vs. pure secondary and tertiary vs. non-tertiary as our relative supply measure. The implications for demand and supply are similar to those obtained in the main results.

${ }^{23}$ The first-stage results are presented in the appendix Table A8.

${ }^{24}$ We would have liked to perform additional specification check using urban female sample separately, but due to limited number of observations in wage sample for few age groups in certain years, we could not implement our empirical strategy.
} 
different age groups are not perfectly substitutable and obtain the elasticity of substitution between different age groups and the two education groups. Our findings regarding demand and supply are quite robust to alternative specifications and samples used.

Our findings regarding demand shifts are consistent with Chamarbagwala (2006). Chamarbagwala (2006) finds that demand increased during 1987-1993 and 1993-1999 and was possibly stable during 1983-1987. But our findings indicate that demand in favor of tertiary graduates increased during 1983-87 also. ${ }^{25}$ In addition, our findings indicate that relative supply combined with shift in demand has a potential to explain why tertiary-secondary wage premium was stable in 1980s and increased in late 1990s.

Given these findings, three important questions arise. First, what accounts for the shift in favor of tertiary or highly skilled workers? Second, why is there no evidence of a break in demand for skilled labor in post-1991 reform era? And third, what accounts for the stagnation in the relative supply of tertiary workers?

Kijima (2006) finds that the share of tertiary graduates (or skilled workers) within each industry increased in most industries and concludes that it indicates that skill-biased technological change has taken place. Also following Autor et al. (1998), Kijima (2006) decomposed the change in the share of skilled workers over time into within- and between-industry shifts and finds that most of the changes in the share of skilled workers are accounted for by within-industry shifts. Chamarbargwala (2006) using demand shift index proposed in Katz and Murphy (1992) also finds that between sector demand shifts are smaller than within sector demand shift. The overall increase in demand shift was caused by within industries skill upgrading. So, skill biased technological change is the most probable reason for shift in demand in favor of tertiary graduate workers. Skill-biased technological change is consistent with our assumption of a linear trend for demand change (Murphy et al., 1998).

Regarding why there is no evidence of a break in demand in 1991, one should keep in mind that the 1980s were quite different from the previous three decades. After experiencing three decades of a low 'Hindu rate of growth' of around three percent a year, the Indian economy grew at a much faster rate (5-6\%) in the 1980s. The average growth rate between 1981-82 and 1990-91 was 5.7 percent, while the annual growth rate during the eleven-year period from 1992-93 to 2002-03 was 5.9 percent. Thus, the growth rates in the 1980s and 1990s were comparable (Panagariya, 2004). In addition, while the conventional wisdom traces the policy

\footnotetext{
${ }^{25}$ Note our relative wage and relative supply measure are different from Chamarbagwala ( 2006). Chamarbargwala (2006) uses relative wage measure which is actual wage in year $t, W_{t}(100 \times 1$ vector, defined for 100 distinct labor groups) deflated by $N^{\prime} W$, where $\mathrm{N}$ is $100 \times 1$ vector of average employment share over the four study years for 100 labor groups. Similarly, the relative supply measure in each year is actual supplies, $X_{t}$ deflated by total supply in the economy measured in efficiency units $\Omega^{\prime} X$, where $\Omega$ is $(100 \times 1)$ vector of average relative wages over the four study years.
} 
reform to the 1990s, many policy reforms were introduced during 1980s. Panagariya (2004) points out that the reforms in the 1980s must be viewed as a precursor to those in the 1990s, rather than a part of the isolated and sporadic liberalizing actions during the 1960s and 1970s which were often reversed within a short period. The difference between the reforms in the 1980s and those in the 1990s is that the former were limited in scope and without a clear roadmap, whereas the latter were systematic. Thus, from a pure growth perspective, the 1980s and the 1990s were not very different. In addition, some of the reforms took place in the 1980s also. Both Chamarbagwala (2006) and Kijima (2006) find that within industry skill upgrading occurred in 1983-1987 also and skill upgrading within industries have greater affect on labor demand than trade in the 1990s. So, there is no reason to expect the 1990s to be very different from the 1980s as far as increase in demand for tertiary graduate workers is concerned.

Factors' leading to stagnation in the relative supply of tertiary graduate workers is an important question for education policy makers and for future research. ${ }^{26}$ This has important implications for tertiary-secondary wage premium and wage inequality in India given that India is projected to maintain a very high growth rate of around $8-9 \%$ in the near future. One possibility is that the massive expansion of elementary education has not been matched at higher stages. Figure 9 presents transition across different stages of schooling. Only one-fourth of students starting at middle school (class 8) end up enrolling in the first year of tertiary education. Only a certain percentage of that enrolment actually completes tertiary education. It seems that drop outs at each stage remain a major problem for the Indian education system. Given the Indian government's efforts to encourage enrollment in elementary schools, unless the dropout rate at later stages is addressed, the relative supply of tertiary graduates is not going to increase in the near future.

\section{Conclusion}

This paper uses individual-level data from urban India covering approximately two decades (1983-2004) to document the trends in wage premium between tertiary and secondary graduate workers. The findings indicate that the wage premium has not only been increasing, but also the increase has not been similar across different age groups, suggesting imperfect substitutability across different age groups. To explain these trends, the simple demand and supply model developed in Card and Lemieux (2001) that allows for imperfect substitutability across different age groups, is used.

\footnotetext{
${ }^{26}$ Addressing the reasons for stagnation in the relative supply of tertiary graduate workers is beyond the scope of the data used in this paper.
} 
The empirical findings of the paper are fourfold. First, relative supply of tertiary workers was virtually unchanged during 1999-2004. Second, the increase in the wage premium is mostly driven by demand shifts. More importantly, demand shifts occurred in the 1980s as well as in the 1990s. Third, the evolution of relative supply has a potential to explain why the tertiary-secondary wage premium increased in 1990s after a period of relative stability in 1980s. An increasing relative supply of tertiary workers in the 1980s negated some of the demand shift, limiting the increase in the wage premium. But, the late 1990s saw a stability in the relative supply of tertiary workers and the wage premium rose substantially in this period. Fourth, the different age groups are imperfect substitutes. 


\section{References}

[1] Acemoglu, D. (2002), "Technical Change, Inequality and the Labor Market," Journal of Economic Literature, 40, 7-72.

[2] Angrist, J.D. (1996), "Short-Run Demand for Palestinian Labor," Journal of Labor Economics, 14, 425-453.

[3] Arbache, J.S., Dickerson, A. and Green, F. (2004), "Trade Liberalisation and Wages in Developing Countries," The Economic Journal, 114, F73-F96.

[4] Autor, D., Katz, L. and Krueger, A. (1998), "Computing Inequality: Have Computers Changed the Labor Market?," Quarterly Journal of Economics, 113 (4), 1169-1214.

[5] Bhaumik, S.K and Chakrabaty, M. (2007), "Is Education the Panacea for Economic Deprivation of Muslims? Evidence from Wage Earners in India 1987-2004," William Davidson Institute Working Paper, 858.

[6] Blom, A. and Vélez, C.E. (2004), "The Dynamics of the Skill-Premium in Brazil: Growing Demand and Insufficient Supply?," Chapter 11 in Inequality and Economic Development in Brazil, World Bank.

[7] Bound, J. and Johnson, G. (1992), "Changes in the Structure of Wages in the 1980's: An Evaluation of Alternative Explanations," American Economic Review, 82(3), 371-92.

[8] Card, D. and Lemieux, T. (2001), "Can Falling Supply Explain the Rising Return to College for Younger Men? A Cohort-Based Analysis," The Quarterly Journal of Economics, 116(2), 705-746.

[9] Chamarbagwala, R. (2006), "Economic Liberalization and Wage Inequality in India," World Development, 34(12), 1997-2015.

[10] Deaton, A. (2003), "Adjusted Indian Poverty Estimates for 1999-2000" Economic and Political Weekly, Jan 25, 322-6.

[11] Deaton, A. and Kozel, V. (2005), "The Great Indian Poverty Debate," Macmillan India.

[12] Dutta, P.V. (2005), "Accounting for Wage Inequality in India," Poverty Research Unit at Sussex Working Paper, 29.

[13] Ferreira, S.J. (2004), "The Provison of Education and its Impact on College Premium in Brazil," RBE Rio de Janeiro, 58(2), 211-233. 
[14] Green, F., Dickerson, A. and Arbache, J.S. (2001), "A Picture of Wage Inequality and the Allocation of Labor through a Period of Trade Liberalization: The Case of Brazil," World Development, 29, 1923-39.

[15] Juhn, C., Murphy, K. and Pierce, B. (1993), "Wage Inequality and the Rise in Returns to Skill," Journal of Political Economy, 101, 410-442.

[16] Katz, L. and Autor, D. (1999), "Changes in the Wage structure and Earnings inequality," in: Ashenfelter, O., Card, D. (Eds.), Handbook of Labor Economics, Elsevier, Amsterdam, 1463- 1555 .

[17] Katz, L. and Murphy, K. (1992), "Changes in Relative Wages, 1963-1987: Supply and Demand factors," The Quarterly Journal of Economics, 107, 35-78.

[18] Kijima, Y. (2006), "Why did Wage Inequality Increase? Evidence from Urban India 1983-99," Journal of Development Economics, 81(1), 97-117.

[19] Kumar, U. and Mishra, P. (2005), "Trade Liberalization and Wage inequality: Evidence from India," IMF Working Paper, 05/20.

[20] Manacorda, M., Sanchez, C.P. and Schady N. (2005), "Changes in Returns to Education in Latin America: The Role of Demand and Supply of Skills," CEP Discussion Paper, 712.

[21] Murphy, K., Riddell, C. and P. Romer. (1998), "Wages, Skill and Technology in the United States and Canada," NBER Working Paper, 6638.

[22] Panagariya, A. (2004), "India in 1980s and 1990s: A Triumph of Reforms," IMF Working Paper, 04/43.

[23] Pavcnik, N. (2003), "What Explains Skill Upgrading in Less Developed Countries?," Journal of Development Economics, 71, 311-318.

[24] Ravallion, M. and Chen, S. (1997), "What Can New Survey Data tell us About Recent Changes in Distribution and Poverty?," World Bank Economic Review, 11, 357-382.

[25] Santamaría, M. (2000), "External Trade, Skill, Technology and the Recent Increase of Income Inequality in Colombia." Archivos De Economia, 171.

[26] Sen, A. and Himansu (2004), "Poverty and Inequality in India - I , Economic and Political Weekly, September 18, 4247-63. 


\section{A Data Appendix}

\section{Wage Sample and Wage premiums}

The wage sample includes regular wage/salaried workers in age group 23-57 years with exactly a tertiary or secondary education. The wage distribution is trimmed by $0.5 \%$ both at top and bottom for each year for both urban and rural areas. The data has information on wages earned in last week and the numbers of days worked in last week (days are categorized according to intensity of work). The weekly wages reported in survey is used as the sample is restricted to regular salaried workers whose wages might not be directly dependent on the days worked in last week. The wage gaps are estimated in separate regressions for each age group in each year using wage sample of regular workers with exactly a tertiary or secondary degree. Each model include log of real weekly wage as dependent variable and age, dummies for scheduled castes, scheduled tribes, states and tertiary education as independent variables. $^{27}$

\footnotetext{
${ }^{27}$ Dummies for Scheduled Castes and Scheduled Tribes are included as both of theses groups are historically backward and benefit from the affirmative actions from Government of India.
} 


\section{Figure 1: Wage Premium for different skill groups}

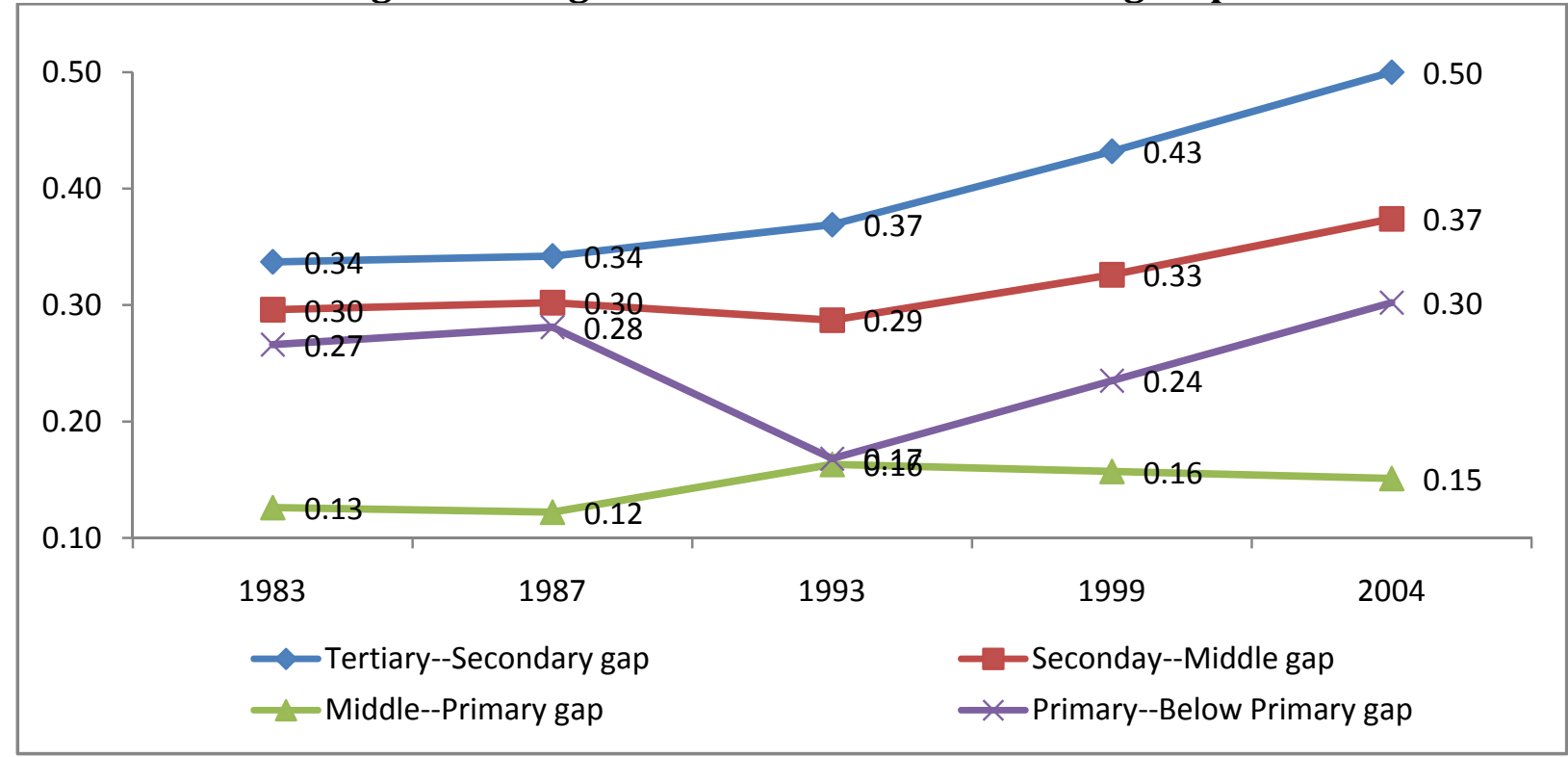

Notes: 1) The wage premiums are estimated in separate regressions in each year using wage sample of regular workers with education level being exactly same as the two education degrees considered.

2) Each model include log of real weekly wage as dependent variable and age, dummies for the higher level of education between the two education levels considered, scheduled castes, scheduled tribes, states as independent variables.

3) Each dummy for the higher level of education between the two education levels considered is statistically significant.

Figure 2: Tertiary-Secondary Wage Premium for different age groups

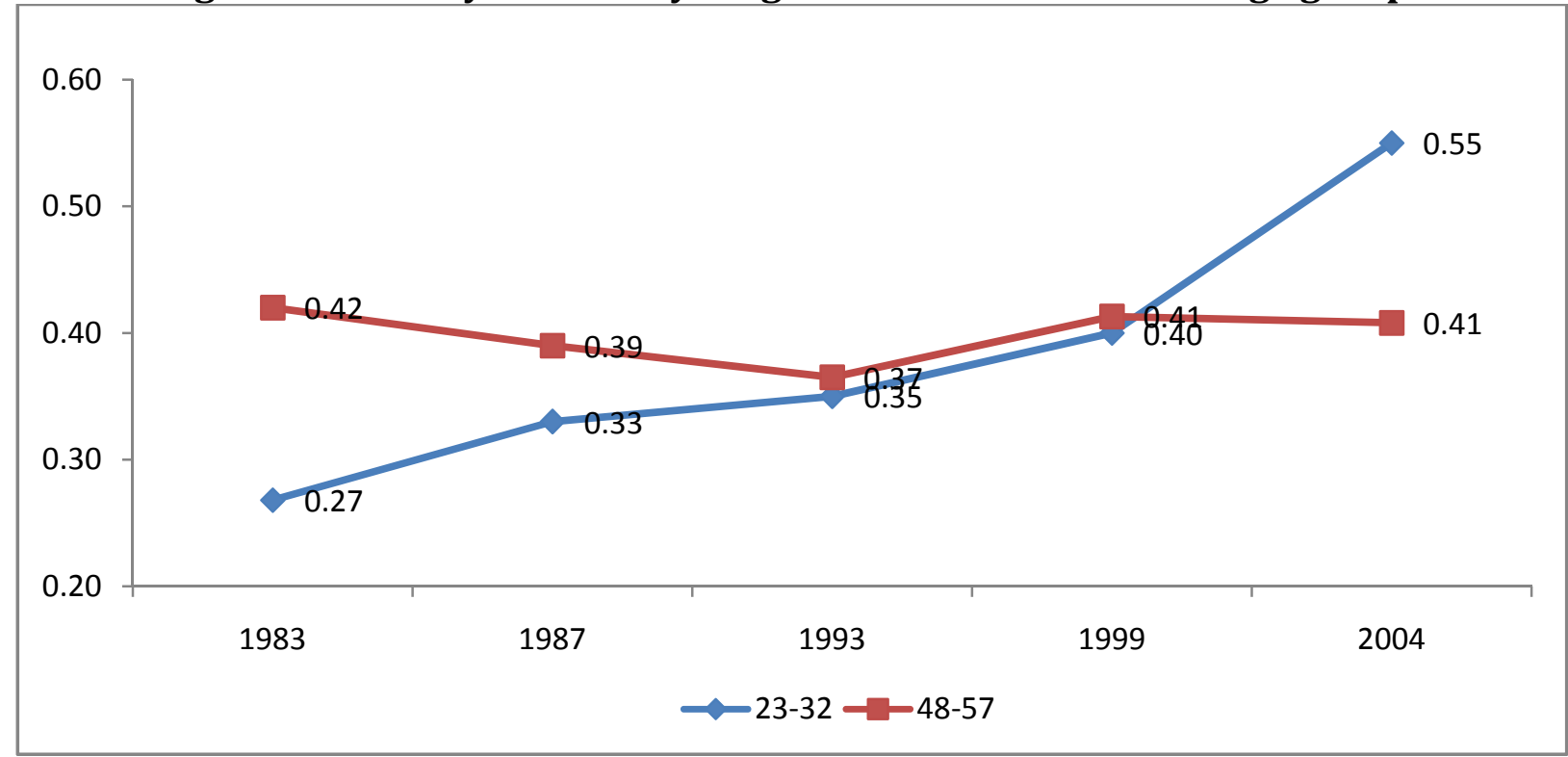

Notes: 1) The wage premiums are estimated in separate regressions for each age group in each year using wage sample of regular workers with exactly a tertiary or a secondary degree.

2) Each model include log of real weekly wage as dependent variable and age, dummies for tertiary education, scheduled castes, scheduled tribes, states as independent variables.

3) Dummy for tertiary education is statistically significant in all years for both age groups. 
Figure 3: Age profile of Tertiary-Secondary Wage Premium at different points of time

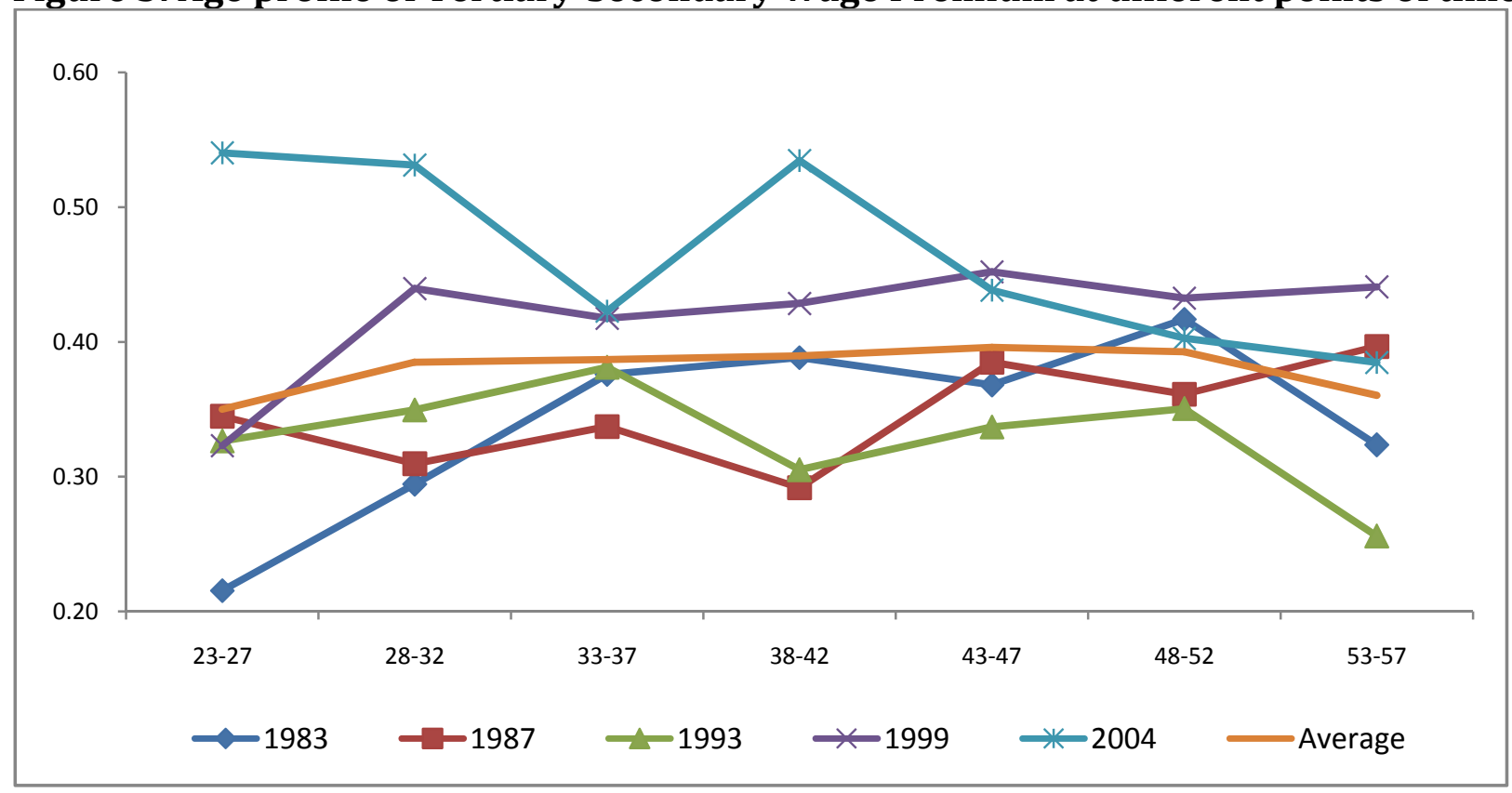

Note: The wage premiums are taken from Table 2.

Figure 4: Age-Profile of Wage Premium for different cohorts

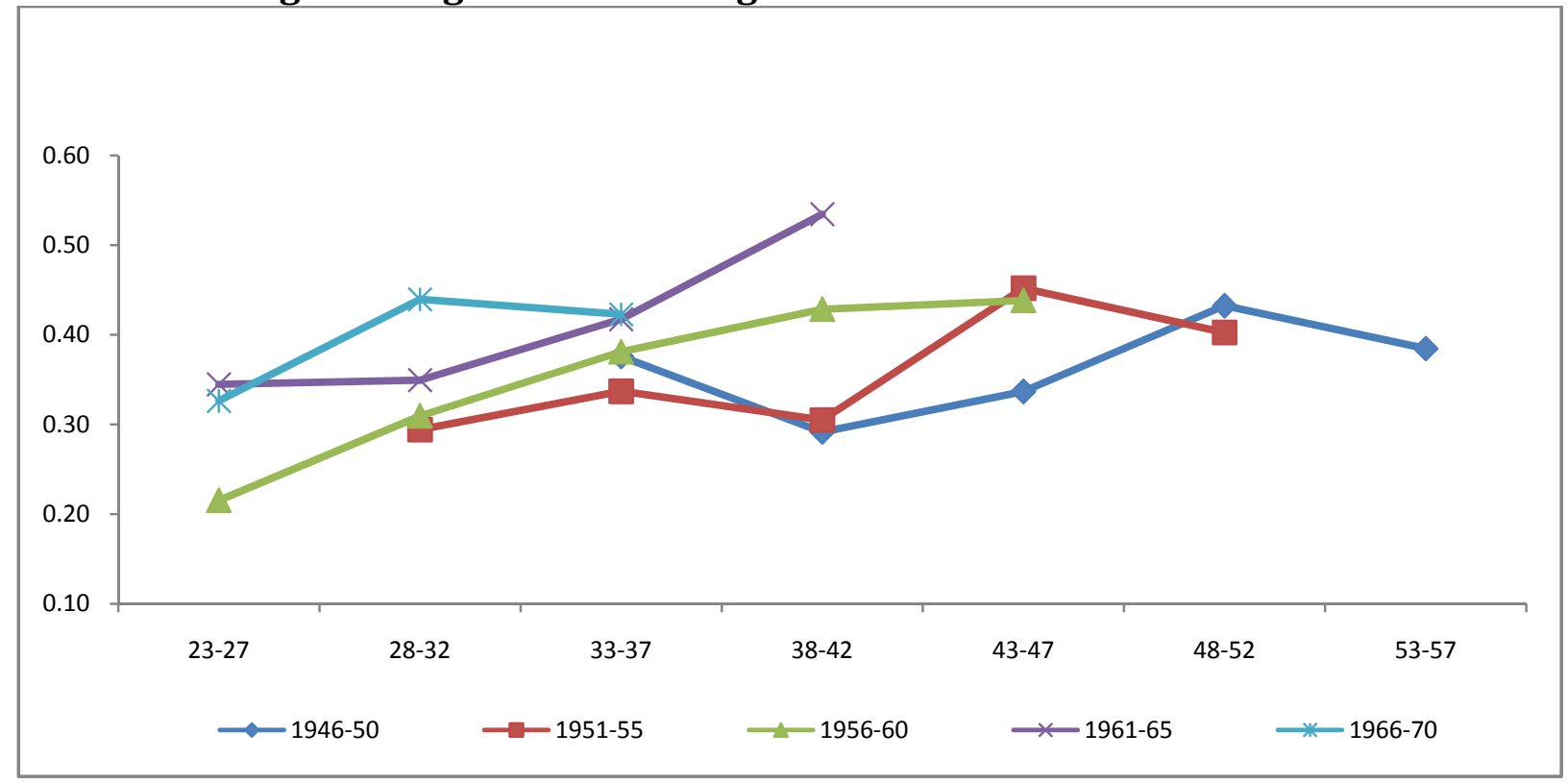

Note: The wage premiums are taken from Table 2. 
Figure 5: Age Group Specific Relative Supply of Tertiary graduate workers

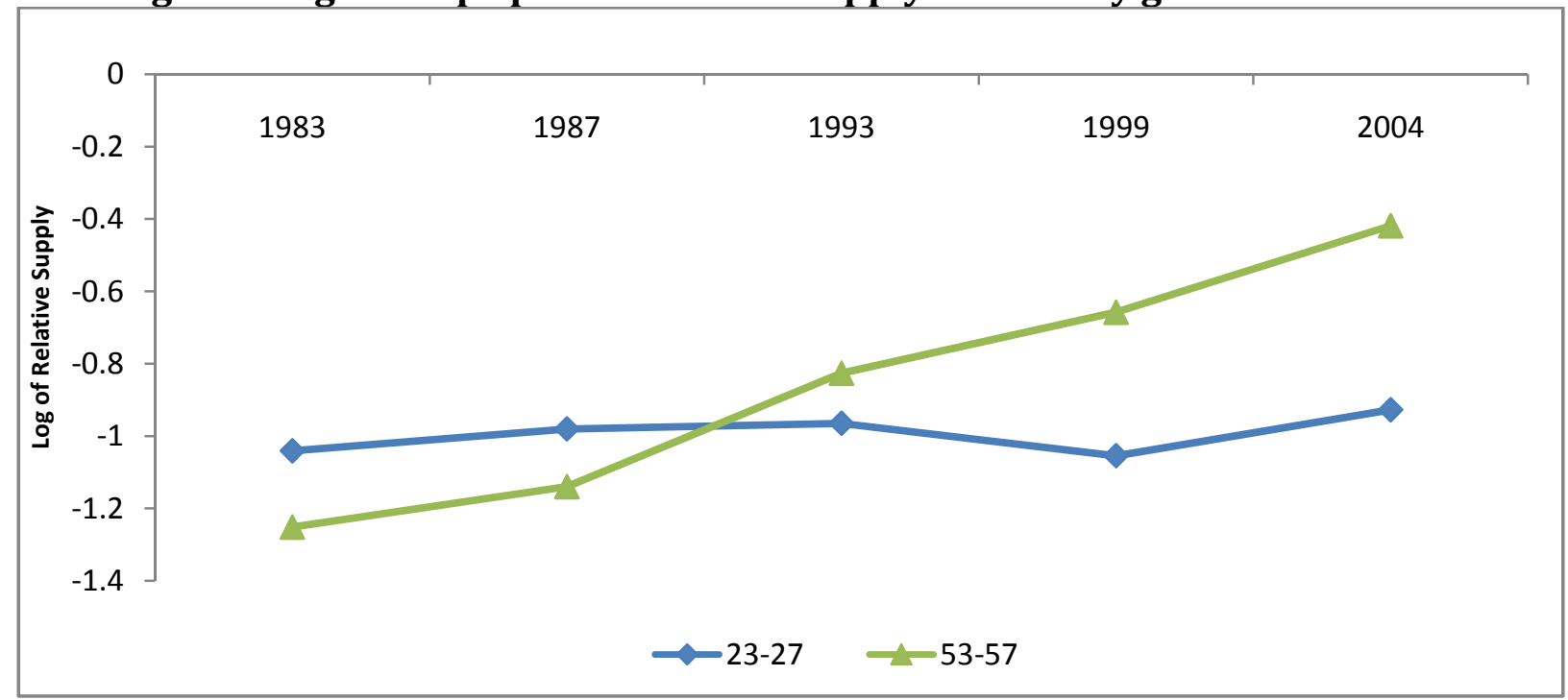

Note: Based on hours supply measure.

Figure 6: Relative Supply of Tertiary graduate workers by cohort

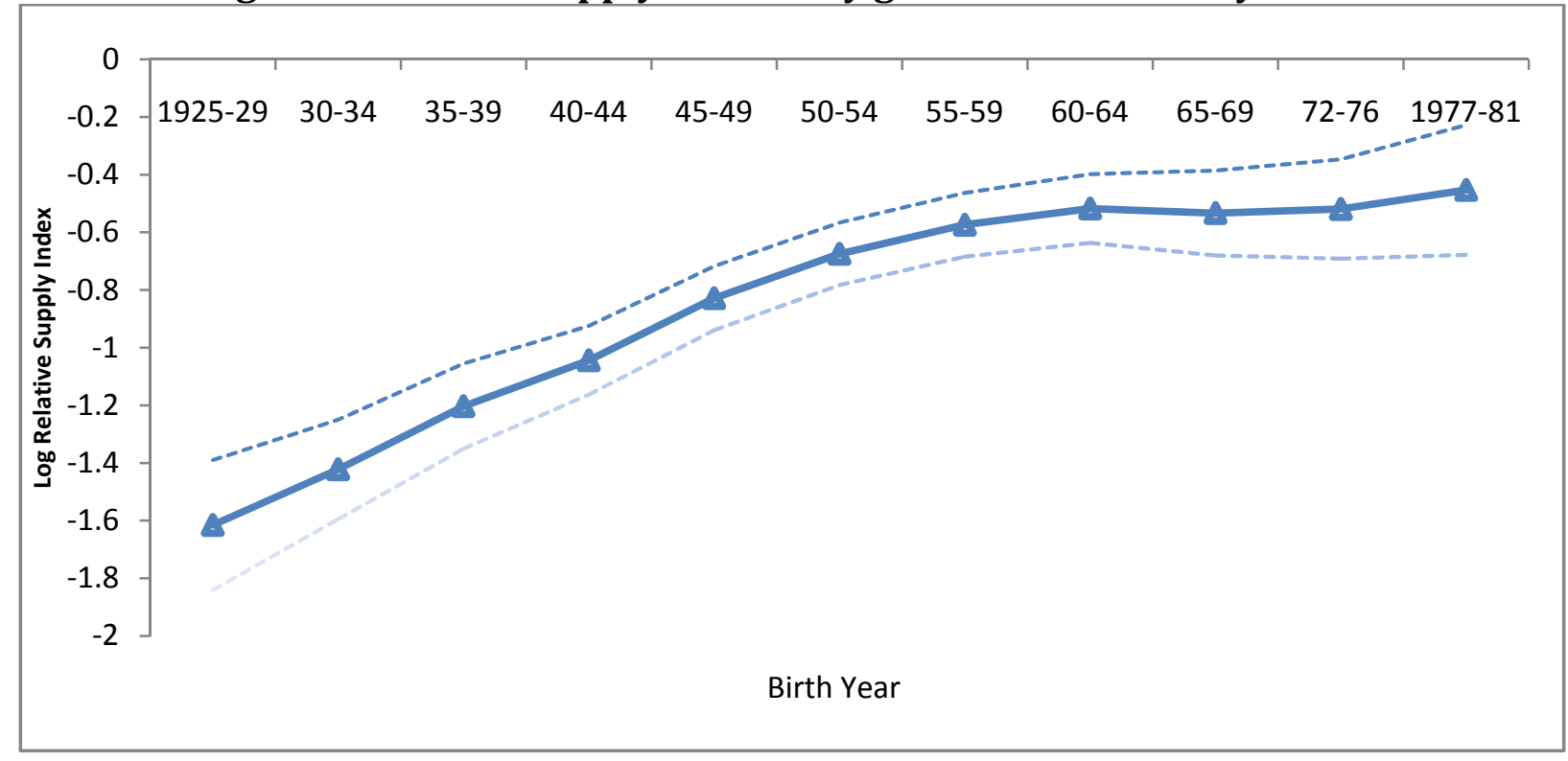

Notes: 1) The cohort effects are standardized for age group 38-42.

2) Based on hours supply measure. 
Figure 7: Aggregate Relative Supply Index for Tertiary graduate workers

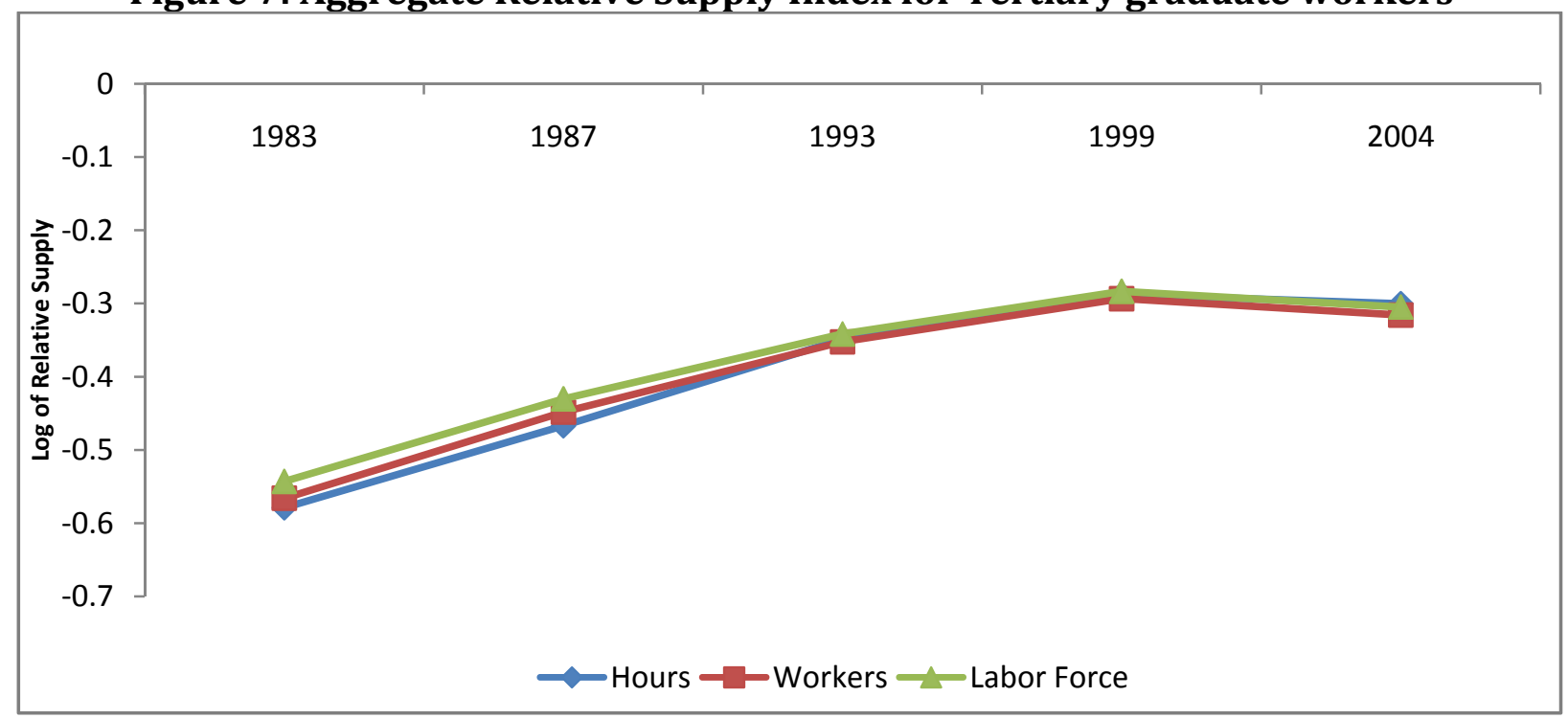




\section{Figure 8: Aggregate Relative Supply Index for Tertiary graduate workers used in Alternative Specifications}

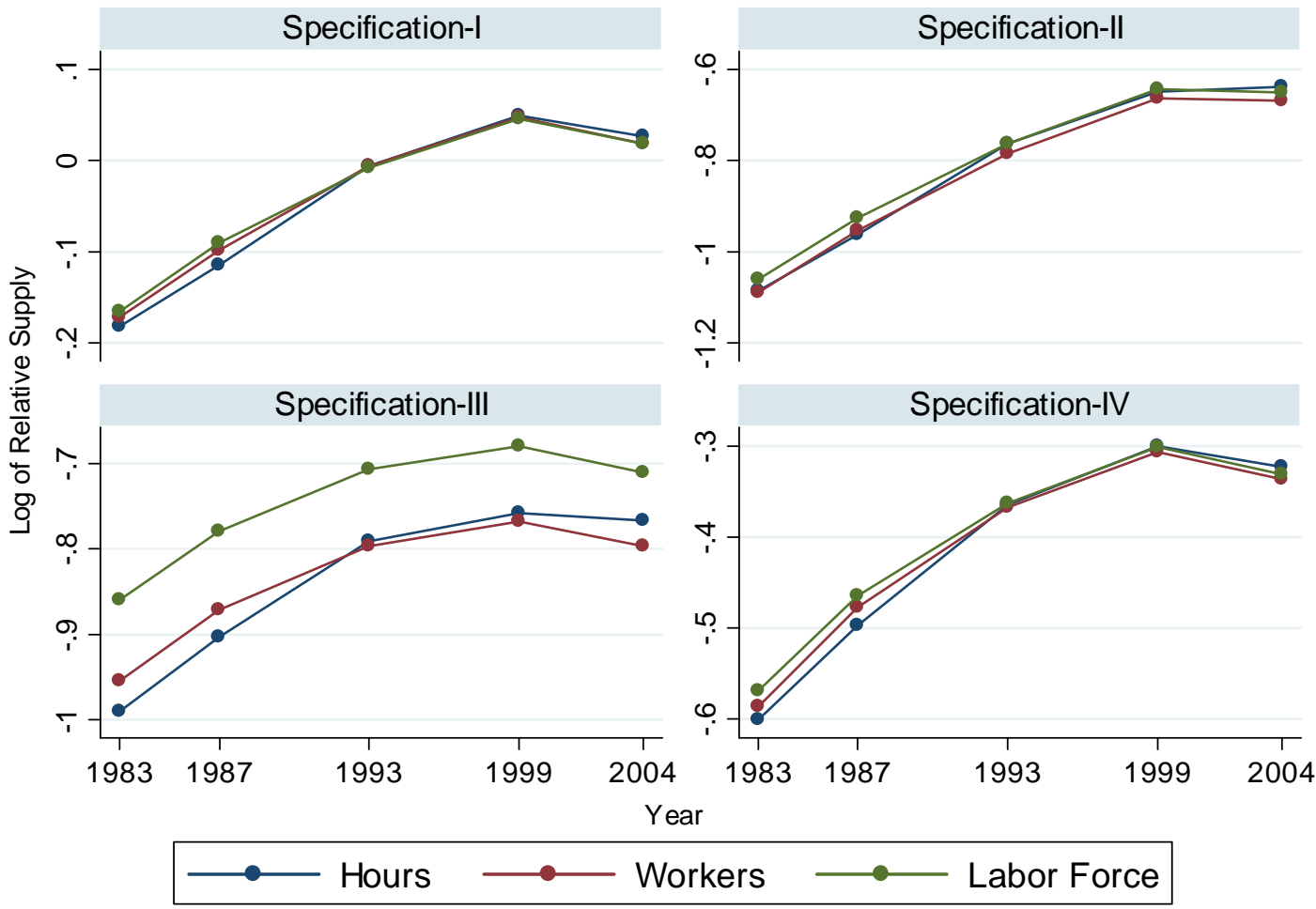

Notes: 1) Specifications refer to alternative specifications used in Section 4.2.

2) Specification I - pure tertiary and pure secondary graduate workers are used to obtain relative supply index.

3) Specification II - workers with education levels below secondary are allocated to secondary weighted by their average wages relative to secondary graduate workers wage.

4) Specification III - urban and rural samples are pooled.

5) Specification IV - urban male sample is used. 
Figure 9: Transition from Middle to Secondary, Sr. Secondary and Tertiary in India

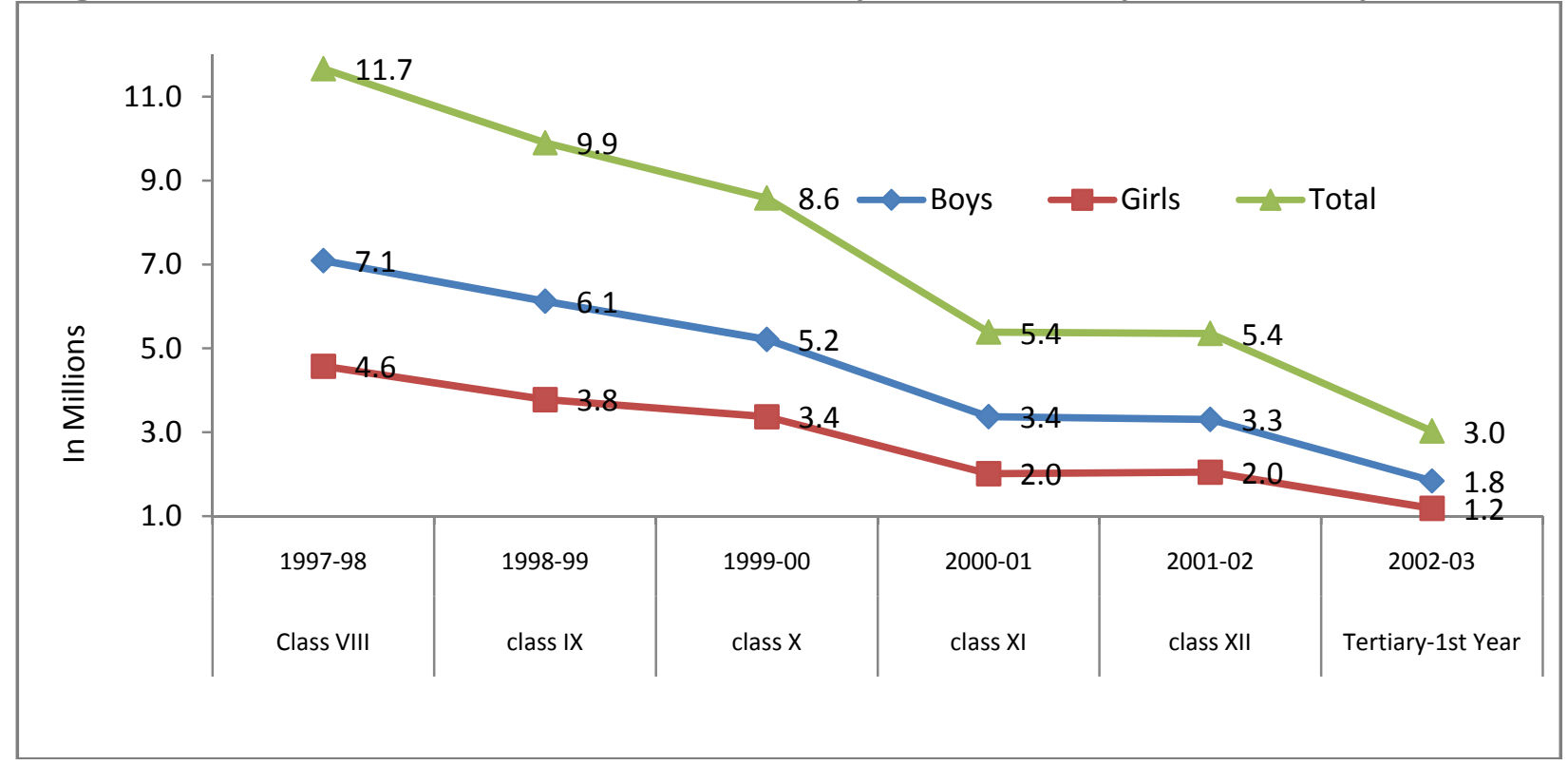

Notes: 1) The figure represents all India.

2) The numbers are enrolment numbers. It can be taken approximately as transition rate assuming that repetition in classes is not quite high.

Source: Selected Educational Statistics, MHRD, GOI, Various Years. 
Table 1: Change in Employment Shares of different educational groups

\begin{tabular}{llllll}
\hline & 1983 & $1987-88$ & $1993-94$ & $1999-00$ & $2004-05$ \\
\hline Below primary & 22.91 & 21.34 & 17.96 & 14.63 & 14.57 \\
Primary & 13.13 & 13.61 & 9.99 & 8.4 & 9.7 \\
Middle & 16.59 & 13.87 & 14.47 & 14.46 & 14.52 \\
Secondary & 28.4 & 29.47 & 31.14 & 32.72 & 31.5 \\
Tertiary & 18.97 & 21.71 & 26.45 & 29.79 & 29.71 \\
\hline No. of observations & $\mathbf{2 2 , 7 5 8}$ & $\mathbf{2 5 , 0 9 1}$ & $\mathbf{2 4 , 5 7 3}$ & $\mathbf{2 5 , 2 9 5}$ & $\mathbf{2 2 , 0 2 0}$ \\
\hline
\end{tabular}

Note: Refers to regular employed workers in age group 23-57 in urban India.

Table 2: Tertiary-Secondary Wage Premium by age group and year

\begin{tabular}{llllllll}
\hline & $23-27$ & $28-32$ & $33-37$ & $38-42$ & $43-47$ & $48-52$ & $53-57$ \\
\hline 1983 & 0.215 & 0.294 & 0.376 & 0.388 & 0.368 & 0.417 & 0.324 \\
& $(0.043)$ & $(0.027)$ & $(0.027)$ & $(0.032)$ & $(0.037)$ & $(0.044)$ & $(0.066)$ \\
1987 & 0.345 & 0.310 & 0.337 & 0.292 & 0.385 & 0.361 & 0.397 \\
& $(0.035)$ & $(0.028)$ & $(0.030)$ & $(0.032)$ & $(0.036)$ & $(0.037)$ & $(0.053)$ \\
1993 & 0.326 & 0.349 & 0.381 & 0.305 & 0.337 & 0.350 & 0.256 \\
& $(0.040)$ & $(0.037)$ & $(0.032)$ & $(0.040)$ & $(0.048)$ & $(0.041)$ & $(0.071)$ \\
1999 & 0.323 & 0.440 & 0.418 & 0.429 & 0.452 & 0.432 & 0.441 \\
& $(0.042)$ & $(0.040)$ & $(0.041)$ & $(0.036)$ & $(0.036)$ & $(0.037)$ & $(0.052)$ \\
2004 & 0.540 & 0.531 & 0.423 & 0.535 & 0.438 & 0.403 & 0.385 \\
& $(0.049)$ & $(0.046)$ & $(0.053)$ & $(0.049)$ & $(0.047)$ & $(0.048)$ & $(0.057)$ \\
\hline
\end{tabular}

Note: Standard errors are in parentheses. The table entries are wage differentials in mean log weekly earnings between a tertiary completed worker and secondary completed worker. 
Table 3: First Stage Estimates for the Tertiary-Secondary Wage Premium

\begin{tabular}{|c|c|c|c|c|c|c|}
\hline & (1) & $(2)$ & (3) & (4) & (5) & (6) \\
\hline & \multicolumn{6}{|c|}{ Measures of Supply } \\
\hline & \multicolumn{2}{|c|}{ Labor Force } & \multicolumn{2}{|c|}{ Workers } & \multicolumn{2}{|c|}{ Hours } \\
\hline 1987 & $\begin{array}{l}0.033 \\
(0.028)\end{array}$ & & $\begin{array}{l}0.025 \\
(0.027)\end{array}$ & & $\begin{array}{l}0.025 \\
(0.027)\end{array}$ & \\
\hline 1993 & $\begin{array}{l}0.063 \\
(0.040)\end{array}$ & & $\begin{array}{l}0.051 \\
(0.036)\end{array}$ & & $\begin{array}{l}0.056 \\
(0.038)\end{array}$ & \\
\hline 1999 & $\begin{array}{l}0.163 \\
(0.047)\end{array}$ & & $\begin{array}{l}0.145 \\
(0.042)\end{array}$ & & $\begin{array}{l}0.151 \\
(0.044)\end{array}$ & \\
\hline 2004 & $\begin{array}{l}0.208 \\
(0.047)\end{array}$ & & $\begin{array}{l}0.191 \\
(0.043)\end{array}$ & & $\begin{array}{l}0.200 \\
(0.045)\end{array}$ & \\
\hline Age Group & -0.200 & -0.245 & -0.168 & -0.216 & -0.171 & -0.218 \\
\hline $\begin{array}{l}\text { Specific Relative } \\
\text { Supply }\end{array}$ & $(0.095)$ & $(0.082)$ & $(0.085)$ & $(0.077)$ & $(0.084)$ & $(0.077)$ \\
\hline trend & & $\begin{array}{l}0.059 \\
(0.011)\end{array}$ & & $\begin{array}{l}0.054 \\
(0.010)\end{array}$ & & $\begin{array}{l}0.057 \\
(0.011)\end{array}$ \\
\hline Adjusted $R^{2}$ & 0.985 & 0.984 & 0.984 & 0.983 & 0.984 & 0.984 \\
\hline $\begin{array}{l}F \\
\text { (p-value) }\end{array}$ & $\begin{array}{l}186.733 \\
(0.000)\end{array}$ & $\begin{array}{l}239.021 \\
(0.000)\end{array}$ & $\begin{array}{l}183.100 \\
(0.000)\end{array}$ & $\begin{array}{l}231.690 \\
(0.000)\end{array}$ & $\begin{array}{l}184.660 \\
(0.000)\end{array}$ & $\begin{array}{l}233.439 \\
(0.000)\end{array}$ \\
\hline $\mathrm{N}$ & 35 & 35 & 35 & 35 & 35 & 35 \\
\hline
\end{tabular}

Note: Standard errors in parenthesis. Models are fitted by weighted least squares to the age group specific wage premiums by year shown in Table 2 . Weights used are inverse of the sampling variances of the estimated wage premiums.

Table 4: Second Stage Estimates for the Tertiary-Secondary Wage Premium

\begin{tabular}{lllllll}
\hline & $(1)$ & $(2)$ & $(3)$ & $(4)$ & $(5)$ & $(6)$ \\
\hline & \multicolumn{7}{c}{ Measures of Supply } \\
\cline { 2 - 7 } & Labor & Workers & Hours & Labor & Workers & Hours \\
& Force & & & Force & & \\
\cline { 2 - 7 } Trend & 0.071 & 0.071 & 0.077 & 0.073 & 0.072 & 0.077 \\
& $(0.018)$ & $(0.017)$ & $(0.020)$ & $(0.018)$ & $(0.018)$ & $(0.020)$ \\
Aggregate Relative & -0.464 & -0.481 & -0.491 & -0.428 & -0.451 & -0.511 \\
Supply & $(0.248)$ & $(0.231)$ & $(0.237)$ & $(0.278)$ & $(0.263)$ & $(0.296)$ \\
Age Group Specific & -0.197 & -0.168 & -0.172 & -0.198 & -0.169 & -0.171 \\
Relative Supply & $(0.097)$ & $(0.086)$ & $(0.085)$ & $(0.099)$ & $(0.088)$ & $(0.087)$ \\
Post 1991 dummy & & & & -0.012 & -0.010 & 0.005 \\
& & & & $(0.038)$ & $(0.039)$ & $(0.043)$ \\
\hline Adjusted $R^{2}$ & 0.984 & 0.984 & 0.984 & 0.983 & 0.983 & 0.983 \\
$\mathrm{~F}$ & 214.159 & 212.391 & 214.081 & 187.636 & 185.849 & 186.946 \\
(p-value) & $(0.000)$ & $(0.000)$ & $(0.000)$ & $(0.000)$ & $(0.000)$ & $(0.000)$ \\
\hline $\mathrm{N}$ & 35 & 35 & 35 & 35 & 35 & 35 \\
\hline
\end{tabular}

Note: Standard errors in parenthesis. Models are fitted by weighted least squares and weights used are inverse of sampling variances of the estimated wage premium. 
Table 5: Second Stage Estimates for the Tertiary-Secondary Wage Premium for pure Tertiary and pure Secondary supply measure

\begin{tabular}{llll}
\hline & $(1)$ & \multicolumn{3}{c}{$(2)$} & $(3)$ \\
\hline \multirow{3}{*}{ Variable } & \multicolumn{3}{c}{ Measure of Supply } \\
\cline { 2 - 4 } & $\begin{array}{l}\text { Labor } \\
\text { Force }\end{array}$ & Workers & Hours \\
\cline { 2 - 4 } Trend & & & \\
& 0.066 & 0.065 & 0.066 \\
Aggregate Relative & $(0.018)$ & $(0.018)$ & $(0.019)$ \\
Supply & -0.504 & -0.511 & -0.465 \\
Age Group Specific & $(0.312)$ & $(0.292)$ & $(0.291)$ \\
Relative Supply & -0.192 & -0.165 & -0.170 \\
& $(0.104)$ & $(0.092)$ & $(0.092)$ \\
\hline Adjusted $R^{2}$ & & & \\
F & 0.983 & 0.982 & 0.982 \\
(p-value) & 199.479 & 197.15 & 194.883 \\
\hline $\mathrm{N}$ & $(0.000)$ & $(0.000)$ & $(0.000)$ \\
\hline $\mathrm{N}$ & 35 & 35 & 35 \\
\hline
\end{tabular}

Note: Standard errors in parenthesis. Models are fitted by weighted least squares and weights used are inverse of sampling variances of the estimated wage premiums.

Table 6: Second Stage Estimates for the Tertiary-Secondary Wage Premium for Tertiary and Non-Tertiary supply measure

\begin{tabular}{llll}
\hline & $(1)$ & \multicolumn{3}{c}{$(2)$} & $(3)$ \\
\hline \multirow{3}{*}{ Variable } & \multicolumn{3}{c}{ Measure of Supply } \\
\cline { 2 - 4 } & $\begin{array}{l}\text { Labor } \\
\text { Force }\end{array}$ & Workers & Hours \\
\cline { 2 - 4 } Trend & & & \\
& 0.070 & 0.070 & 0.080 \\
Aggregate Relative & $(0.025)$ & $(0.025)$ & $(0.026)$ \\
Supply & -0.313 & -0.329 & -0.308 \\
Age Group Specific & $(0.208)$ & $(0.205)$ & $(0.203)$ \\
Relative Supply & -0.172 & -0.156 & -0.155 \\
& $(0.074)$ & $(0.060)$ & $(0.068)$ \\
\hline Adjusted $R^{2}$ & & & \\
F & 0.983 & 0.983 & 0.983 \\
(p-value) & 208.638 & 205.656 & 205.811 \\
\hline $\mathrm{N}$ & $(0.000)$ & $(0.000)$ & $(0.000)$ \\
\hline
\end{tabular}

Note: Standard errors in parenthesis. Models are fitted by weighted least squares and weights used are inverse of sampling variances of the estimated wage premiums. 
Table 7: Second Stage Estimates for the Tertiary-Secondary Wage Premium for All India Sample

\begin{tabular}{|c|c|c|c|}
\hline & $(1)$ & $(2)$ & (3) \\
\hline & \multicolumn{3}{|c|}{ Measure of Supply } \\
\hline & $\begin{array}{l}\text { Labor } \\
\text { Force }\end{array}$ & Workers & Hours \\
\hline Trend & $\begin{array}{l}0.053 \\
(0.011)\end{array}$ & $\begin{array}{l}0.053 \\
(0.012)\end{array}$ & $\begin{array}{l}0.065 \\
(0.014)\end{array}$ \\
\hline Aggregate Supply Index & $\begin{array}{l}-0.383 \\
(0.229)\end{array}$ & $\begin{array}{l}-0.417 \\
(0.224)\end{array}$ & $\begin{array}{l}-0.481 \\
(0.213)\end{array}$ \\
\hline $\begin{array}{l}\text { Age-Group Specific } \\
\text { Relative supply }\end{array}$ & $\begin{array}{l}-0.207 \\
(0.101) \\
\end{array}$ & $\begin{array}{l}-0.178 \\
(0.088)\end{array}$ & $\begin{array}{l}-0.159 \\
(0.085)\end{array}$ \\
\hline Adjusted $R^{2}$ & 0.988 & 0.988 & 0.989 \\
\hline $\begin{array}{l}F \\
\text { (p-value) } \\
\end{array}$ & $\begin{array}{l}293.684 \\
(0.000) \\
\end{array}$ & $\begin{array}{l}292.133 \\
(0.000) \\
\end{array}$ & $\begin{array}{l}302.282 \\
(0.000) \\
\end{array}$ \\
\hline $\mathrm{N}$ & 35 & 35 & 35 \\
\hline
\end{tabular}

Table 8: Tertiary-Secondary Wage Premium by age groups and year for Urban Male

\begin{tabular}{rrrrrrrr}
\hline & \multicolumn{1}{c}{$23-27$} & \multicolumn{1}{c}{$28-32$} & \multicolumn{1}{c}{$33-37$} & \multicolumn{1}{c}{$38-42$} & \multicolumn{1}{c}{$43-47$} & \multicolumn{1}{c}{$48-52$} & \multicolumn{1}{c}{$53-57$} \\
\hline 1983 & 0.224 & 0.303 & 0.389 & 0.393 & 0.378 & 0.436 & 0.396 \\
& $(0.050)$ & $(0.028)$ & $(0.030)$ & $(0.034)$ & $(0.039)$ & $(0.047)$ & $(0.065)$ \\
1987 & 0.349 & 0.312 & 0.343 & 0.290 & 0.392 & 0.374 & 0.432 \\
& $(0.039)$ & $(0.030)$ & $(0.032)$ & $(0.035)$ & $(0.035)$ & $(0.038)$ & $(0.057)$ \\
1993 & 0.374 & 0.362 & 0.385 & 0.332 & 0.350 & 0.340 & 0.252 \\
& $(0.044)$ & $(0.041)$ & $(0.034)$ & $(0.044)$ & $(0.050)$ & $(0.044)$ & $(0.072)$ \\
1999 & 0.318 & 0.458 & 0.410 & 0.461 & 0.480 & 0.455 & 0.443 \\
& $(0.041)$ & $(0.043)$ & $(0.045)$ & $(0.039)$ & $(0.038)$ & $(0.039)$ & $(0.049)$ \\
2004 & 0.631 & 0.540 & 0.392 & 0.573 & 0.476 & 0.443 & 0.429 \\
& $(0.055)$ & $(0.050)$ & $(0.056)$ & $(0.054)$ & $(0.049)$ & $(0.051)$ & $(0.062)$ \\
\hline
\end{tabular}

Note: Standard errors are in parentheses. The table entries are wage differentials in mean log weekly earnings between a tertiary completed worker and secondary completed worker. 
Table 9: Second Stage Estimates for the Tertiary-Secondary Wage Premium for Male Sample

\begin{tabular}{|c|c|c|c|}
\hline & (1) & $(2)$ & (3) \\
\hline & \multicolumn{3}{|c|}{ Measure of Supply } \\
\hline & $\begin{array}{l}\text { Labor } \\
\text { Force }\end{array}$ & Workers & Hours \\
\hline \multirow[t]{2}{*}{ Trend } & 0.080 & 0.080 & 0.083 \\
\hline & $(0.021)$ & $(0.021)$ & $(0.023)$ \\
\hline Aggregate Supply & -0.562 & -0.572 & -0.540 \\
\hline Index & $(0.281)$ & $(0.265)$ & $(0.266)$ \\
\hline Age-Group Specific & -0.176 & -0.145 & -0.153 \\
\hline Relative supply & $(0.115)$ & $(0.103)$ & $(0.102)$ \\
\hline Adjusted $R^{2}$ & 0.979 & 0.979 & 0.978 \\
\hline $\mathrm{F}$ & 161.835 & 160.642 & 158.482 \\
\hline (p-value) & $(0.000)$ & $(0.000)$ & $(0.000)$ \\
\hline $\mathrm{N}$ & 35 & 35 & 35 \\
\hline
\end{tabular}




\section{Appendix}

Table A1: Education System in India

\begin{tabular}{ll}
\hline Education Level & Years of Education \\
\hline Tertiary & 15 or more \\
Secondary & $10-12$ \\
Middle & 8 \\
Primary & 5 \\
\hline Note: There is some state wise variation for Primary/Middle.
\end{tabular}

Table A2: Estimated Cohort and Age effects in Age Specific Relative Supply of Tertiary graduate workers

\begin{tabular}{|c|c|c|c|}
\hline & (1) & (2) & (3) \\
\hline & \multicolumn{3}{|c|}{ Measure of Supply } \\
\hline & Hours & Workers & Labor Force \\
\hline Age 23-27 & $-0.47 * * *$ & $-0.44 * * *$ & $-0.34 * * *$ \\
\hline Age 28-32 & $-0.21 * * *$ & $-0.18 * * *$ & $-0.18 * * *$ \\
\hline Age 33-37 & $-0.10^{*}$ & -0.09 & $-0.10^{*}$ \\
\hline Age $43-47$ & $0.10^{*}$ & $0.10^{*}$ & $0.10^{*}$ \\
\hline Age 48-52 & $0.23 * * *$ & $0.20 * * *$ & $0.21 * * *$ \\
\hline Age 53-57 & $0.36 * * *$ & $0.34 * * *$ & $0.34 * * *$ \\
\hline Cohort 1 & $-1.62 * * *$ & $-1.60 * * *$ & $-1.59 * * *$ \\
\hline Cohort 2 & $-1.42 * * *$ & $-1.36 * * *$ & $-1.37 * * *$ \\
\hline Cohort 3 & $-1.20 * * *$ & $-1.17 * * *$ & $-1.17 * * *$ \\
\hline Cohort 4 & $-1.04 * * *$ & $-1.02 * * *$ & $-1.03 * * *$ \\
\hline Cohort 5 & $-0.83 * * *$ & $-0.82 * * *$ & $-0.82 * * *$ \\
\hline Cohort 6 & $-0.67 * * *$ & $-0.67 * * *$ & $-0.68 * * *$ \\
\hline Cohort 7 & $-0.57 * * *$ & $-0.59 * * *$ & $-0.60 * * *$ \\
\hline Cohort 8 & $-0.52 * * *$ & $-0.55 * * *$ & $-0.54 * * *$ \\
\hline Cohort 9 & $-0.53 * * *$ & $-0.58 * * *$ & $-0.55 * * *$ \\
\hline Cohort 10 & $-0.52 * * *$ & $-0.57 * * *$ & $-0.51 * * *$ \\
\hline Cohort 11 & $-0.45 * * *$ & $-0.52 * * *$ & $-0.47 * * *$ \\
\hline Adjusted $R^{2}$ & 0.99 & 0.99 & 0.99 \\
\hline $\mathrm{F}$ & 200.32 & 221.5 & 213.13 \\
\hline (p-value) & $(0.00)$ & $(0.00)$ & $(0.00)$ \\
\hline $\mathrm{N}$ & 35 & 35 & 35 \\
\hline & & $* \mathrm{p}<0.1 ; * *$ & $\bar{p}<.05 ; * * * \mathrm{p}$ \\
\hline
\end{tabular}


Table A3: Estimated efficiencies parameters for different age groups

\begin{tabular}{lllllll}
\hline & \multicolumn{2}{l}{$\begin{array}{l}\text { Tertiary efficiency parameters } \\
\beta^{\prime} s\end{array}$} & \multicolumn{6}{c}{$\begin{array}{l}\text { Secondary efficiency parameters } \\
\alpha^{\prime} s\end{array}$} \\
\hline \multirow{2}{*}{ Age Group } & \multicolumn{7}{c}{ Measures of Supply } \\
\cline { 2 - 7 } $23-27$ & 1.00 & 1.00 & 1.00 & 1.00 & 1.00 & 1.00 \\
\cline { 2 - 7 } $28-32$ & 1.29 & 1.33 & 1.33 & 1.26 & 1.28 & 1.29 \\
$33-27$ & 1.43 & 1.50 & 1.50 & 1.39 & 1.43 & 1.43 \\
$38-42$ & 1.61 & 1.69 & 1.69 & 1.56 & 1.62 & 1.62 \\
$43-47$ & 1.66 & 1.77 & 1.77 & 1.63 & 1.71 & 1.71 \\
$48-52$ & 1.76 & 1.89 & 1.88 & 1.74 & 1.84 & 1.84 \\
$53-57$ & 1.60 & 1.75 & 1.74 & 1.68 & 1.81 & 1.80 \\
\hline
\end{tabular}

Note: Standardized to age group 23-27

Table A4: International evidences on estimates of elasticity of substitution

\begin{tabular}{lll}
\hline Author & Elasticity & Country \\
\hline A. & & \\
\hline Katz and Murphy (1992) & 1.41 & USA \\
Santamaria (2000) & 2.1 & Colombia \\
Angrist (1996) & 2 & Palestine \\
Blom and Veléz (2004) & 1.6 & Brazil(Urban) \\
\hline B & & \\
\hline Card and Lemieux (2001) & $1.1-1.6$ & USA \\
& $2-2.5^{*}$ & USA,UK,Canada \\
Ferreira (2004) & 1.9 & Brazil (Urban) \\
\hline
\end{tabular}

Notes: ) Studies in group A assume perfect substitutability across age groups.

2) Studies in group B do not assume perfect substitutability.

3) * Only takes male sample. 
Table A5: Estimated First Stage Results for pure Tertiary and Secondary supply measure

\begin{tabular}{|c|c|c|c|c|c|c|}
\hline & (1) & (2) & (3) & (4) & (5) & (6) \\
\hline & \multicolumn{6}{|c|}{ Measure of Supply } \\
\hline Variable & \multicolumn{2}{|c|}{ Labor Force } & \multicolumn{2}{|c|}{ Workers } & \multicolumn{2}{|c|}{ Hours } \\
\hline \multirow[t]{2}{*}{1987} & 0.020 & & 0.015 & & 0.014 & \\
\hline & $(0.026)$ & & $(0.025)$ & & $(0.025)$ & \\
\hline \multirow[t]{2}{*}{1993} & 0.047 & & 0.038 & & 0.041 & \\
\hline & $(0.036)$ & & $(0.033)$ & & $(0.034)$ & \\
\hline \multirow[t]{2}{*}{1999} & 0.144 & & 0.129 & & 0.134 & \\
\hline & $(0.043)$ & & $(0.038)$ & & (0.039) & \\
\hline \multirow[t]{2}{*}{2004} & 0.188 & & 0.175 & & 0.181 & \\
\hline & $(0.042)$ & & (0.039) & & $(0.04)$ & \\
\hline Age Group Specific & -0.190 & -0.236 & -0.160 & -0.205 & -0.164 & -0.204 \\
\hline Relative Supply & $(0.099)$ & $(0.091)$ & (0.089) & $(0.085)$ & $(0.088)$ & (0.085) \\
\hline \multirow[t]{2}{*}{ Trend } & \multirow{2}{*}{\multicolumn{3}{|c|}{$\begin{array}{l}0.053 \\
(0.011)\end{array}$}} & 0.049 & & 0.050 \\
\hline & & & & $(0.010)$ & & $(0.010)$ \\
\hline \multirow{3}{*}{$\begin{array}{l}\text { Adjusted } R^{2} \\
\mathrm{~F} \\
\text { (p-value) }\end{array}$} & 0.984 & 0.983 & 0.984 & 0.982 & 0.984 & 0.982 \\
\hline & 181.288 & 223.149 & 178.476 & \multirow{2}{*}{$\begin{array}{l}217.267 \\
(0.000) \\
\end{array}$} & 179.949 & 217.478 \\
\hline & $(0.000)$ & $(0.000)$ & $(0.000)$ & & $(0.000)$ & $(0.000)$ \\
\hline $\mathrm{N}$ & 35 & 35 & 35 & 35 & $35 \quad 3$ & 35 \\
\hline \multicolumn{7}{|c|}{$\begin{array}{l}\text { Note: Standard errors in parenthesis. Models are fitted by weighted least squares and weights used are } \\
\text { inverse of sampling variances of the estimated wage premiums. }\end{array}$} \\
\hline & (1) & (2) & (3) & (4) & (5) & (6) \\
\hline & \multicolumn{6}{|c|}{ Measure of Supply } \\
\hline Variable & \multicolumn{2}{|c|}{ Labor Force } & \multicolumn{2}{|c|}{ Workers } & \multicolumn{2}{|c|}{ Hours } \\
\hline \multirow[t]{2}{*}{1987} & 0.032 & & 0.026 & & 0.025 & \\
\hline & $(0.026)$ & & $(0.025)$ & & $(0.025)$ & \\
\hline 1993 & 0.077 & & 0.066 & & 0.073 & \\
\hline & (0.039) & & $(0.037)$ & & $(0.038)$ & \\
\hline 1999 & 0.191 & & 0.175 & & 0.181 & \\
\hline & $(0.050)$ & & $(0.046)$ & & $(0.047)$ & \\
\hline 2004 & 0.241 & & 0.226 & & 0.236 & \\
\hline & $(0.051)$ & & $(0.048)$ & & $(0.051)$ & \\
\hline Age Group Specific & -0.178 & -0.193 & -0.160 & 0.062 & -0.160 & -0.175 \\
\hline Relative Supply & (0.069) & $(0.065)$ & $(0.065)$ & $(0.013)$ & $(0.063)$ & $(0.061)$ \\
\hline Trend & & 0.066 & & -0.178 & & 0.064 \\
\hline & & $(0.013)$ & & $(0.063)$ & & $(0.013)$ \\
\hline Adjusted $R^{2}$ & 0.986 & 0.984 & 0.985 & 0.983 & 0.986 & 0.984 \\
\hline $\mathrm{F}$ & 202.261 & 237.509 & 198.143 & 231.924 & 200.208 & 233.347 \\
\hline (p-value) & $(0.000)$ & $(0.000)$ & $(0.000)$ & $(0.000)$ & $(0.000)$ & $(0.000)$ \\
\hline$N$ & 35 & 35 & 35 & 35 & 35 & 35 \\
\hline
\end{tabular}

Note: Standard errors in parenthesis. Models are fitted by weighted least squares and weights used are inverse of sampling variances of the estimated wage premiums. 
Table A7: Estimated First Stage Results for both Urban and Rural areas-All India

\begin{tabular}{|c|c|c|c|c|c|c|}
\hline & (1) & (2) & (3) & (4) & (5) & (6) \\
\hline & \multicolumn{6}{|c|}{ Measures of Supply } \\
\hline & \multicolumn{2}{|c|}{ Labor Force } & \multicolumn{2}{|c|}{ Workers } & \multicolumn{2}{|c|}{ Hours } \\
\hline 1987 & $\begin{array}{l}0.057 \\
(0.023)\end{array}$ & & $\begin{array}{l}0.052 \\
(0.022)\end{array}$ & & $\begin{array}{l}0.050 \\
(0.022)\end{array}$ & \\
\hline 1993-94 & $\begin{array}{l}0.063 \\
(0.032)\end{array}$ & & $\begin{array}{l}0.053 \\
(0.029)\end{array}$ & & $\begin{array}{l}0.057 \\
(0.032)\end{array}$ & \\
\hline 1999-00 & $\begin{array}{l}0.141 \\
(0.037)\end{array}$ & & $\begin{array}{l}0.129 \\
(0.032)\end{array}$ & & $\begin{array}{l}0.132 \\
(0.036)\end{array}$ & \\
\hline 2004-05 & $\begin{array}{l}0.186 \\
(0.034)\end{array}$ & & $\begin{array}{l}0.176 \\
(0.031)\end{array}$ & & $\begin{array}{l}0.185 \\
(0.037)\end{array}$ & \\
\hline $\begin{array}{l}\text { Age-Specific Relative } \\
\text { Supply }\end{array}$ & $\begin{array}{l}-0.205 \\
(0.099)\end{array}$ & $\begin{array}{l}-0.244 \\
(0.082)\end{array}$ & $\begin{array}{l}-0.177 \\
(0.087)\end{array}$ & $\begin{array}{l}-0.218 \\
(0.077)\end{array}$ & $\begin{array}{l}-0.158 \\
(0.086)\end{array}$ & $\begin{array}{l}-0.213 \\
(0.076)\end{array}$ \\
\hline Trend & & $\begin{array}{l}0.048 \\
(0.008)\end{array}$ & & $\begin{array}{l}0.045 \\
(0.008)\end{array}$ & & $\begin{array}{l}0.049 \\
(0.009)\end{array}$ \\
\hline Adjusted $R^{2}$ & 0.989 & 0.988 & 0.989 & 0.988 & 0.988 & 0.988 \\
\hline $\begin{array}{l}F \\
\text { (p-value) }\end{array}$ & $\begin{array}{l}255.585 \\
(0.000)\end{array}$ & $\begin{array}{l}333.661 \\
(0.000)\end{array}$ & $\begin{array}{l}254.232 \\
(0.000)\end{array}$ & $\begin{array}{l}325.767 \\
(0.000)\end{array}$ & $\begin{array}{l}247.013 \\
(0.000)\end{array}$ & $\begin{array}{l}325.655 \\
(0.000)\end{array}$ \\
\hline $\mathrm{N}$ & 35 & 35 & 35 & 35 & 35 & 35 \\
\hline
\end{tabular}

Note: Standard errors in parenthesis. Models are fitted by weighted least squares and weights used are inverse of sampling variances of the estimated wage premiums.

Table A8: Estimated First Stage Results for Urban Male Sample

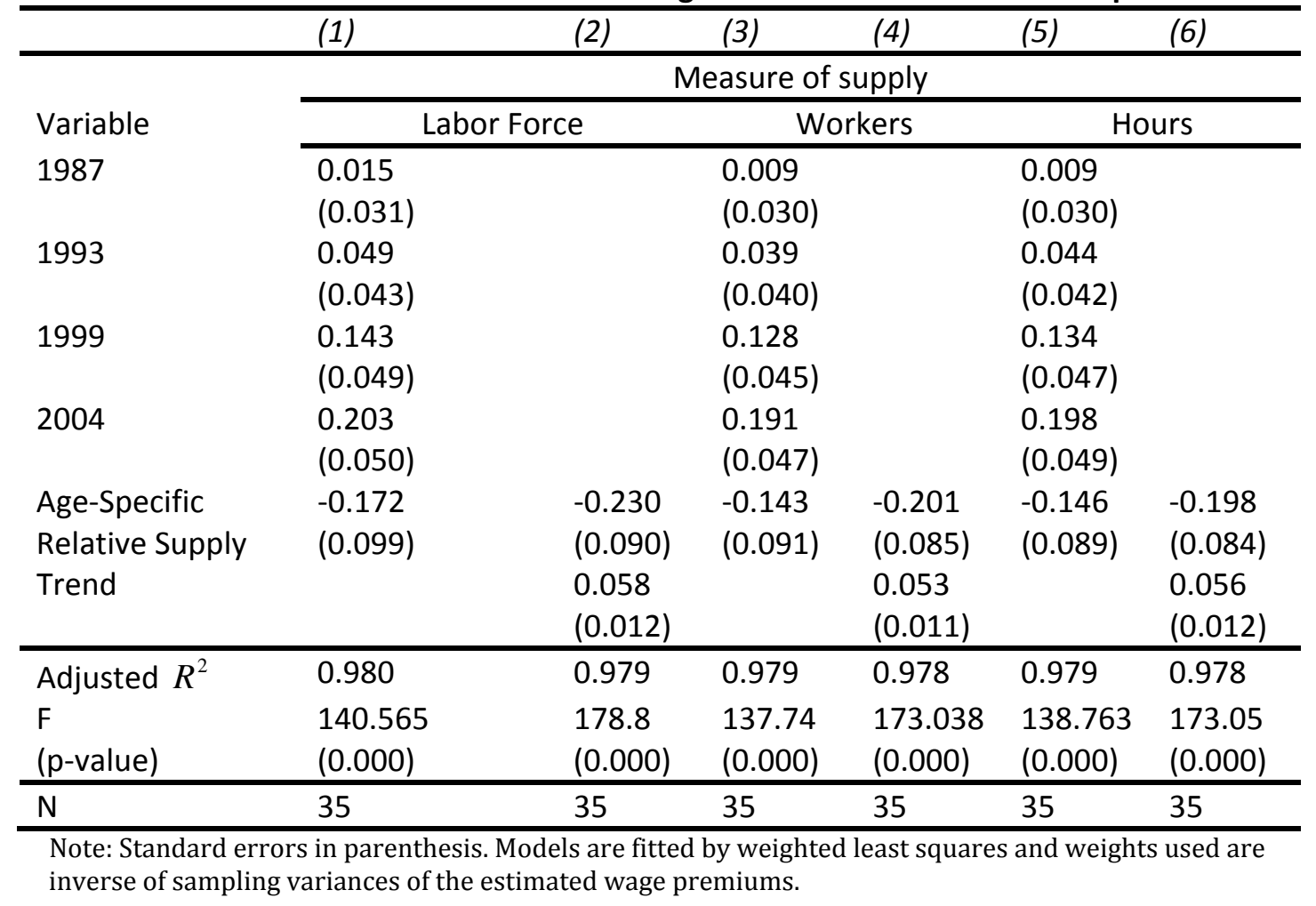

